\title{
Identification of a New Microalgal Strain From Chromite Mine Wastes for Detoxification of Hexavalent Chromium for Sustainable Crop Growth
}

Pritikrishna Majhi

Odisha University of Agriculture and Technology

Gyana Ranjan Rout

Odisha University of Agriculture and Technology

Saubhagya Manjari Samantaray ( $\sim$ saubhagyasamantaray@yahoo.com )

Odisha University of Agriculture and Technology

\section{Research Article}

Keywords: Cr6+, cyanobacteria, detoxification, Fischerella sp. (MK422171), in vitro, plant growth promotion

Posted Date: September 13th, 2021

DOI: https://doi.org/10.21203/rs.3.rs-848133/v1

License: () (i) This work is licensed under a Creative Commons Attribution 4.0 International License. Read Full License 


\section{Abstract}

Sukinda chromium mine is well known for its chromium ( $\mathrm{Cr}$ ) reserve in India. It accounts for $97 \%$ of $\mathrm{Cr}$ production in the country. The open cast mining results in the seepage and accumulation of chromium in the nearby paddy fields through soil runoff. Deposition of high concentrations of toxic $\mathrm{Cr}^{6+}$ adversely affected the growth and productivity of rice plants. It was studied that $\mathrm{Cr}^{6+}$ toxicity can be counteracted by the microbes especially algae. Hence, an attempt has been made for the exploration of an indigenous micro-algal strain for the detoxification of $\mathrm{Cr}^{6+}$ in the rice fields. Three different micro-algal strains were isolated from the waterlogged regions of the mine waste area and tested against $\mathrm{Cr}^{6+}$. The average concentration of $\mathrm{Cr}^{6+}$ in the soils of rice fields and its surrounding regions was estimated around $40 \mathrm{ppm}$. In vitro study was conducted to determine the optimal growth parameters for the growth of the algal strains. The concentration of total chromium availability was determined by using ICP-OES (Inductively coupled plasma atomic emission spectroscopy. It showed that all the algal-stains were able to detoxify $\mathrm{Cr}^{6+}$, but the best result (89.63\%) was observed in one strain 'SM3'. SEM-EDX study also showed that there was no $\mathrm{Cr}$ adsorbed on the surface of the algal strain. Raman Spectroscopy study confirmed the reduction of $\mathrm{Cr}^{6+}$ to $\mathrm{Cr}^{3+}$ in algal strain. The strain was identified as Fischerella sp. (Accession no. MK422171) through morphological and molecular characterization. This algal strain can be used for the bioremediation of chromium contaminated crop fields.

\section{Introduction}

Naturally available chromium in the earth's crust has immense industrial applications, especially in stainless steel, tannery, paper pulp, and electro-plating industries (Monograph on chromite, 2013; Katircioglu et al. 2012). In nature, chromium occurs in several oxidative forms, of which hexavalent Cr and trivalent $\mathrm{Cr}$ are the most stable and available forms for use (Dwivedi et al. 2010). Chromium in trivalent form is considered as non-toxic or less toxic while its hexavalent form is more toxic and carcinogenic (Singhvi and Chhabra, 2013), hence, requires environmental cleansing especially in chromium mine waste. Odisha, is rich in its mineral reserve and it has the lion's share of $98 \%$ in the context of total chromium (Cr) reserve in India (Mishra and Sahu, 2013), mostly concentrated in the Sukinda Valley of Jajpur district which holds $97 \%$ of total share of the state (Monograph on chromite, 2013).The Cr extraction in the mining site follows open cast mining procedure, which leads to seepage of toxic $\mathrm{Cr}^{6+}$ to the nearby areas through soil run off and causes contamination to local biota especially in the paddy fields (Hayat et al. 2012). It has been reported that chromium accumulates in different plant parts such as shoot, root, leaves and grains (Ahmad et al. 2011) and results in abnormal growth and reduced the crop yield (Shanker et al. 2005). Pigment content of the leaves, rate of photosynthesis, nitrogen, potassium, phosphorus content in the root and shoot get reduced due to the high concentration of $\mathrm{Cr}^{6+}$ deposition in soil and hence, leads to less growth and productivity (Panda and Chaudhury, 2005). It is also subjected to bio-magnifications in the food chain and ultimately reaches to human being (Chatterjee and Abraham, 2015). The consumption of rice grains containing good amount of hexavalent chromium invites health hazards like irritation in lungs and stomach, damage in respiratory tract, inflammation, dermatitis, bronchitis, ulcers and cancer that leads to death (Abdel-Ghani et al. 2014). Hence, environment clean-up of $\mathrm{Cr}^{6+}$ is of utmost essential in the chromite mine waste and its adjoining regions. The toxicity of the $\mathrm{Cr}^{6+}$ can be reduced by various conventional methods like physical and chemical process (Elhaddad and Abeer, 2015), but are very expensive and also appears to unsafe (Belattmania et al. 2015). Keeping in view of these afore referred facts, development of novel approach like detoxification of $\mathrm{Cr}^{6+}$ using biological methods seems to be the need of the hour (Esmaeili et al. 2010). Micro-organisms help in detoxification of $\mathrm{Cr}^{6+}$ through the process of biotransformation or biosorption (Pagnanelli et al. 1997). Among the micro-organisms, algae draw a lot of attention for the detoxification of various metal pollutants as reported (Brahmabhatt et al. 2012). These photosynthetic autotrophic nitrogen fixing organisms grow abundantly in waterlogged conditions (Banerjee et al. 2004). Rice cultivation requires a standing water level in the field for most of its life cycle (Bhattacharyya et al. 2005) and provides the natural condition for algae to grow. Algae can withstand against various concentrations of toxic metals and are potential source of heavy metal remediation (Davis et al. 2003; Volesky et al. 2007). It has also been proved that algae are capable of detoxify heavy metals through biosorption (Gupta et al. 2008) and bio-transformation (Bender et al. 1995). Apart from that algae can also bring in noticeable improvements in the soil texture and quality (Paudel et al. 2012), hence, enhancing the soil fertility through atmospheric nitrogen fixation (Padhy et al. 2016). As per our observation, it is imperative to mention that many chromium resistant local micro-algal strains are available in the water logged places of the Sukinda mining area and they can be used for the bioremediation of chromium contaminated soil of rice fields (Sundarmoorthy et al. 2010). Hence, an attempt has been made in the present study to characterise a potential micro-algal strain is capable of detoxification of $\mathrm{Cr}^{6+}$ in the chromium contaminated rice fields.

\section{Material And Methods}

\subsection{Physicochemical properties of rice field soil}

Soil samples were collected rice field of four different locations in Sukinda chromite mine in Odisha, India. Fig.1 showed the sample collection sites where S1, S2, S3 and S4 referred to four different paddy fields from where the soil samples were collected and the red marked region was the mining area from where the algal samples were collected. About $250 \mathrm{gms}$ of soil samples were collected from each location a time and kept in zipper bags, taken to the laboratory. The $\mathrm{pH}$ and temperature of the soil samples were recorded by using $\mathrm{pH}$ meter and thermometer on their sampling sites. The samples were mixed together to estimate their $\mathrm{Cr}$ content and other physicochemical parameters such as moisture content, electrical conductivity, total dissolve solid etc (Pattnaik et al. 2017).

\subsection{Collection of algal samples and maintenance of pure cultures}

The algal samples along with water and soil were collected in different zipper bags from the water logged places of the mining sites. Different algal samples were thoroughly washed (4-5 times) through running tap water and then with distilled water. The samples were cultured and sub-cultured repeatedly in their specific growth medium to obtain the pure cultures of three algal strains named as SM1, SM2 and SM3 respectively. SM1 and SM2 were grown in BG11 medium (Stainer et al. 1971) but SM3 was cultured in nitrate free Allen and Arnon medium (Allen and Arnon, 1955). The algal samples were maintained at 
$28 \pm 2^{0} \mathrm{C}$ with $42 \mu \mathrm{mol}$ photons $\mathrm{m}^{-2} \mathrm{~s}^{-1}$ light intensity using cool white fluorescent lamps under laboratory conditions (Kiran et al. 2008, Majhi and Samantaray, 2021).

\subsection{Growth of algal isolates at different concentrations of $\mathrm{Cr}^{6+}$}

The isolated algal strains were allowed to grow in $100 \mathrm{ml}$ of respective media containing varying concentrations of $\mathrm{Cr}^{6+}(0$ to $200 \mathrm{mg} / \mathrm{L})$ for 30 days. Cell growth was determined by taking the dry cell weight of all the strains at 4 days interval. The cultures were centrifuged by taking them in pre-weighed $60 \mathrm{ml}$ centrifuge falcon tubes at $16,000 \mathrm{rpm}$ for $10 \mathrm{~min}$. Then, the supernatant was discarded and the pellets formed were placed in a hot air oven at $65^{\circ} \mathrm{C}$ (until the final weight became constant). Now, the dried pellets along with the tube were weighed and the final weight was calculated by subtracting the initial weight of the centrifuge tube from the final one containing the cell pellets (Bottomley and Van-Baalen, 1978; Razi, 2006).

\subsection{Growth optimization of the algal isolates}

Growth conditions such as $\mathrm{pH}$, inoculum size and photoperiod of the three algal strains were optimised at 40ppm $\mathrm{Cr}^{6+}$ containing medium (according to Majhi and Samantaray, 2020a, 40ppm is the average concentration of chromium in the rice fields of Sukinda mining area) to observe their growth and to find out the maximum biomass producing algal strain (Majhi and Samantaray, 2021).

\subsection{Analysis of total chromium and hexavalent chromium}

The chromium reduction assay was carried out by growing the algal isolates in 1 lit of culture medium supplemented with $40 \mathrm{ppm}$ of $\mathrm{K}_{2} \mathrm{Cr}_{2} \mathrm{O}_{7}$ solution. Then,

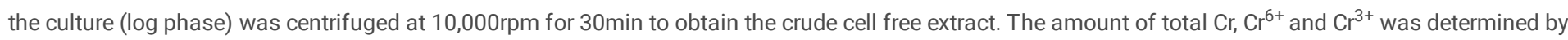
following Majhi and Samantaray, 2021. The organism showing maximum $\mathrm{Cr}^{6+}$ removal was selected for further study.

\subsection{Effect of agitation time}

The effect of agitation time on $\mathrm{Cr}^{6+}$ removal by the selected organism was determined by taking 5 numbers of conical flasks, each containing $50 \mathrm{~mL}$ of medium (distilled water having $40 \mathrm{mg} / \mathrm{L}$ concentration of $\left.\mathrm{Cr}^{6+}\right)$ and were placed in an orbital incubated shaker at $28 \pm 2^{0} \mathrm{C}$ with different agitation times $(24,48$, 72,96 and 120 hours). These samples were centrifuged separately and then filtered through Whatman filter papers grade no. 41 . These filtrates were tested for the final concentrations of chromium remaining in the aqueous solution by DPC method (Kavitha et al. 2016).

\subsection{Study on chromium adsorption}

The chromium adsorption by the algal isolates was studied through scanning electron microscope-energy dispersive X-Ray (SEM-EDX) and Fourier transmission infra-red spectroscopy (FTIR) analysis (Majhi and Samantaray, 2021).

\subsection{Study on chromium absorption}

\subsubsection{TEM analysis}

For the TEM analysis, the control and hexavalent chromium treated cyanobacterial cultures were centrifuged at 10,000rpm for 10min, washed thrice with saline phosphate buffer solution (PBS, pH 7.4). Then, it was re-suspended in $1 \mathrm{~mL}$ of fixative solution ( $2.5 \%$ glutaraldehyde and $2 \%$ formaldehyde) and kept for 6 hour at $4^{\circ} \mathrm{C}$. The post fixation and fixative solutions were separated by centrifugation. The cell pellet was then washed five times with PBS and again resuspended in $1 \mathrm{~mL}$ of sodium phosphate buffer. Aliquots of the cell suspension were mounted on 400 mesh Cu grids and allowed to dry overnight in a desiccator. Microscopic images of these cells were taken on a Tecnai Transmission Electron Microscope operated at $200 \mathrm{kV}$ accelerating voltage (Das et al. 2014).

\subsection{Study on chromium reduction}

\subsubsection{Raman spectroscopy}

Raman spectroscopy was carried out for the analysis of hexavalent and trivalent chromium in the $\mathrm{Cr}^{6+}$ treated media and inside the cell of treated organism (Majhi and Samantaray, 2021).

\subsection{Identification of the algal isolate}

\subsubsection{Microscopic observation}

The potent algal isolate was identified under light microscope and phase contrast microscope following the standard algal monograph (Desikachary, 1959).

\subsubsection{Molecular identification}

Molecular identification of the algal isolate was carried out by $16 \mathrm{~S}$ rDNA sequencing. The extraction of DNA was conducted by DNeasy Plant Mini Kit (Qiagen).

\section{Amplification of 16S rDNA and sequencing}


The extracted DNA was sent to SRM-DBT, Tamilnadu, India for $16 \mathrm{~S}$ rDNA sequencing. The extracted DNA quality was evaluated on $1.0 \%$ TAE agarose gel electrophoresis using 1kb DNA ladder. Fragment of 16S rDNA gene was amplified and a single discrete PCR amplicon band resolved on agarose gel. Then, the amplified product was purified to remove contaminants. Forward and reverse DNA sequencing reaction of PCR amplicon was carried out with CYA106F, CYA359F and CYA781R ( $\mathrm{a}+\mathrm{b})$ using Big Dye Terminator v3.1 Cycle sequencing kit on Applied Biosystem ${ }^{\text {TM }}$ SeqStudio ${ }^{\text {TM }}$ Genetic Analyzer. Consensus sequence of 16S rDNA was analysed by Bio-Edit software v7.0.5.3 and submitted to NCBI for generation of accession number.

\section{Evolutionary analysis}

The submitted16S rDNA sequence of the cyanobacterial isolate was subjected to multiple sequence analysis using ClustalW v1.6. Then phylogenetic tree was constructed using neighbour joining method (Saitou and Nei, 1987) of MEGA v 7.0 (Molecular Evolutionary Genetic Analysis) software (Tamura et al. 2013). The resultant phylogenetic tree topologies were evaluated by bootstrap analysis of neighbour- joining data sets based on 1000 resampling.

\subsection{Effect of the selected alga on the growth performance of $\mathrm{Cr}^{6+}$ treated rice plants}

\subsubsection{Selection of rice seeds for the experiments}

Certified healthy seeds of Oryza sativa (Var. Lalata) were procured from the Department of Plant Breeding and Genetics, College of Agriculture, Odisha University of Agriculture \& Technology, Bhubaneswar, India for the experiment during the Kharif and Rabi season of the year 2019. This crop matures in about 120 days.

\subsubsection{Pot culture experiments under axenic conditions}

Plant growth experiments were conducted in 12" plastics pots for six different treatments. Each pot contained air dried sterilised garden soil along with different proportion of $\mathrm{Cr}^{6+}$ rich mine spoil. The experiment was performed in triplicates for each of the six treatments. Three inoculated seedlings were transplanted with uniform distance in each pot aseptically. The experiment was carried out under normal environmental condition during the Rabi and Kharif season (Two seasons) during the year 2018 \& 2019. Before and after transplantation, all the physico-chemical parameters of the soil were measured. The six different treatments of the experiments were as follows:

Treatment no. $1\left(\mathrm{~T}_{1}\right)$ : $500 \mathrm{gm}$ of $\mathrm{Cr}^{6+}$ containing chromite mine spoil collected from paddy field $(100 \%)+1$ litre Cyanobacterial inoculums

Treatment no. $2\left(\mathrm{~T}_{2}\right): 75 \% \mathrm{Cr}^{6+}$ containing chromite mine spoil collected from paddy field +1 litre Cyanobacterial inoculums+ $25 \%$ normal garden soil.

Treatment no. $3\left(\mathrm{~T}_{3}\right): 250 \mathrm{gm}$ of $\mathrm{Cr}^{6+}$ containing chromite mine spoil collected from paddy field (50\%)+ Cyanobacterial inoculums+ $50 \%$ normal garden soil

Treatment no. $4\left(\mathrm{~T}_{4}\right): 150 \mathrm{gm}$ of $\mathrm{Cr}^{6+}$ containing chromite mine spoil collected from paddy field $(25 \%)+$ Cyanobacterial inoculums+ $75 \%$ normal garden soil

Treatment no. $5\left(T_{5}\right)$ : Normal garden soil (control)

Treatment no. $6\left(\mathbf{T}_{6}\right)$ : $\mathrm{Cr}^{6+}$ mine soil collected from paddy field (100\%)

\subsubsection{Physico-chemical analysis of the plant samples}

\section{Number of tillers}

The number of functional tillers were counted and recorded at each 30 days interval.

\section{Number of leaves}

The number of functional leaves were counted and recorded at each 30 days interval.

\section{Shoot and root height}

The shoot and root height was measured non-destructively using a meter scale at an interval of 30 days and expressed in centimetres.

\section{Seed vigour index}

Seed vigour index (SVI) was calculated by the protocol given by Majhi and Samantaray, 2021.

\section{Shoot and root dry weight}

For the determination of dry biomass, the shoot and root were put in labelled paper bags and placed in an oven at $65^{\circ} \mathrm{C}$ for 48 hours. Then the weight was measured using an electronic weighing balance.

\section{Total leaf area}

The length and breadth of each and every leaf was measured and the total leaf area was calculated by using the formula: $L \times B \times$ Correction factor $x$ No. of leaves 
It is expressed in $\mathrm{cm}^{2} /$ plant where, $\mathrm{L}$ and $\mathrm{B}$ are the length and breadth, respectively and the correction factor was taken as 0.73 .

\section{Number of grains/ panicle}

Total number of grains per panicle was counted manually from each panicle which were selected randomly from each pot. The mean of ten randomly selected panicles from pot were used to determine the number of grains per panicle.

\section{Weight of 1000 seeds}

Thousand healthy grains are randomly selected from the treated and control plants, weighed by the help of an electronic weighing balance.

\subsection{Biochemical analysis of the plant samples}

\subsubsection{Chlorophyll estimation}

Five hundred $\mathrm{mg}$ leaf from each treatment were cut from the composite leaves and were immersed in $50 \mathrm{ml}$ of $80 \%(\mathrm{v} / \mathrm{v})$ acetone in a conical flask and kept in dark for 24 hour for extraction of chlorophyll from the leaf samples. Thereafter, the chlorophyll extracts were centrifuged at $10000 \mathrm{rpm}$ for 10 min. and the supernatant was taken for chlorophyll content analysis. Absorbance of the chlorophyll extract was measured at $645 \mathrm{~nm}$ and $663 \mathrm{~nm}$ using a colorimeter. The amount of chlorophyll-a, chlorophyll-b and total chlorophyll were calculated in $\mathrm{mg} / \mathrm{g}$ fresh weight according to the following equations.

i) Chlorophyll -a (mg/g fresh weight basis )

$$
=12.7 \times\left(\mathrm{OD}_{663}\right)-2.69 \times\left(\mathrm{OD}_{645}\right) \times \frac{\mathrm{V}}{1000 \times \mathrm{W}}
$$

ii) Chlorophyll-b (mg/g fresh weight basis)

$$
=22.9 \times\left(\mathrm{OD}_{645}\right)-4.68 \times\left(\mathrm{OD}_{663}\right) \times \frac{\mathrm{V}}{1000 \times \mathrm{W}}
$$

iii) Total chlorophyll (mg/g fresh wt. of basis)

$$
=20.2 \times\left(\mathrm{OD}_{645}\right)+8.02 \times\left(\mathrm{OD}_{663}\right) \times \frac{\mathrm{V}}{1000 \times \mathrm{W}}
$$

Where

$$
\mathrm{OD}_{645}=\text { Optical density at } 645 \mathrm{~nm}
$$

$\mathrm{OD}_{663}=\quad$ Optical density at $663 \mathrm{~nm}$

$\mathrm{V} \quad=\quad$ Final volume of $80 \%$ acetone chlorophyll extract in $\mathrm{ml}$

W = $\quad$ Fresh weight in $\mathrm{g}$ of fresh leaves used in the extraction of chlorophyll

\subsubsection{Estimation of crude protein content}

Cells in the late exponential phase were taken out from culture flasks and centrifuged at $12,000 \mathrm{rpm}$ for $15 \mathrm{~min}$. and at $4^{\circ} \mathrm{C}$. The cell pellets were homogenized in liquid $\mathrm{N}_{2}$ and suspended in extraction buffers ( $50 \mathrm{mM}$ Tris-HCl buffer $(\mathrm{pH} 7.5)+0.1 \mathrm{mM} \mathrm{PMSF}+1 \mathrm{mM}$ EDTA). The homogenate was then centrifuged at $13000 \mathrm{~g}$ at $4^{\circ} \mathrm{C}$ and supernatant was collected as crude enzyme extracts for assay of enzymatic activity. Estimation of protein was done following modified Bradford assay (1976). Briefly, variable concentration of crude proteins were mixed with $1 \mathrm{ml}$ Bradford reagent and incubated in dark for 15-20min. Absorbance ratio was then taken at $590 \mathrm{~nm}$ and $450 \mathrm{~nm}$ and only Bradford reagent was taken as control. Standard graph was prepared for the Bradford against bovine serum albumin (BSA).

\subsubsection{Catalase activity}

Activity of catalase was measured following methods of Aebi (1983). The enzyme catalase (CAT; EC 1.11.1.6) catalyzes the decomposition of $\mathrm{H}_{2} \mathrm{O}_{2}$ to $\mathrm{H}_{2} \mathrm{O}$ and $\mathrm{O}_{2}$. The reaction mixture was prepared by adding $50 \mathrm{mM}$ potassium phosphate buffer $(\mathrm{pH} 7.2)$ and enzyme extract, $10 \mathrm{mM} \mathrm{H}_{2} \mathrm{O}_{2}$ and decrease in absorbance at 240nm (due to decomposition of $\mathrm{H}_{2} \mathrm{O}_{2}$ ) was recorded using UV-VIS spectrophotometer.

\subsubsection{SOD activity}

Assay of super oxide dismutase (SOD; EC 1.15.1.1) activity in the crude protein was performed using spectrophotometric analysis (Beauchamp and Fridovich, 1971). The extracted crude protein sample was thawed and then kept for some times on ice. All the reagents required for the experiment were pre-warmed to room temperature. The reagents were mixed gently and were taken in duplicates. The reaction mixture was prepared in $50 \mathrm{mM}$ potassium phosphate buffer (pH 7.2) containing $2.45 \mathrm{mM} \mathrm{NBT}, 1.8 \mathrm{mM}$ xanthine and a suitable concentration of xanthine oxidase (for which a linear curve with slope 0.021 absorbance per 
min in time scan at $550 \mathrm{~nm}$ was obtained). One unit of SOD activity was calculated as the amount of protein that reduces the reaction rate of NBT by $50 \%$ in the reaction mixture.

\subsubsection{Estimation of total carbohydrate content}

Dried plant sample $(100 \mathrm{mg})$ was weighed and kept in a boiling tube. The sample was added with $5 \mathrm{ml}$ of $2.5 \mathrm{~N} \mathrm{HCl}$, hydrolysed by keeping it in boiling water bath for 3hours and cooled to room temperature. Then it was neutralize with solid carbonate until the effervescence ceased. The volume was made to $100 \mathrm{ml}$ after transferring the sample in to a $100 \mathrm{ml}$ volumetric flask. $10 \mathrm{ml}$ of the diluted sample was taken in a centrifuge tube and centrifuged for $10 \mathrm{~min}$. at $10,000 \mathrm{rpm}$. The supernatant was then collected from which $0.5 \mathrm{ml}$ and $1 \mathrm{ml}$ of aliquots was taken for further analysis. A standard was prepared by taking 0 , $0.6,1.2,1.6,2.4$ and $3 \mathrm{ml}$ of stock solution where 0 (distilled water) was served as the blank. The volume of all the working solution along the sample were made up to $3 \mathrm{ml}$ with distilled water and finally $12 \mathrm{ml}$ of anthrone reagent was added to each tube. The mixture was then heated for $8 \mathrm{~min}$. in a boiling water bath, cooled rapidly to the room temperature and the absorbance was read at $630 \mathrm{~nm}$ after the conversion of green coloured sample in to dark green colour. The standard graph was plotted by taking the O.D. values of the standard solutions and the amount of carbohydrate was calculated by the following equation (Sadasivam et al. 1992).

Calculation of total amount of carbohydrate present in 100mg of sample

(mg of glucose/ volume of the test sample) $\times 100$

\subsection{Elemental analysis}

The dried algal sample was taken to analyse by $\mathrm{CHNS}(0)$ elemental analyser (Elementar, UNICUBE) to study the organic carbon, hydrogen and nitrogen amount (Tasic et al. 2016). Total carbon, hydrogen and nitrogen content are expressed in terms of mass fractions of the dried sample. The contents of inorganic elements were analysed by ICP-OES in triplicates. (Godlewska et al. 2016, Majhi and Samantaray, 2021).

\subsection{Statistical analysis}

The data were analysed using one way ANOVA in SPSS software version 21. Mean value of the samples were compared using least significant difference (LSD) at $\mathrm{P}<0.05$

\section{Results}

\subsection{Physicochemical parameters analysis}

Table 1 showed the physicochemical properties such as pH, temperature, moisture content, electrical conductivity (EC), total dissolved solid (TDS), chromium content in the soil samples collected from the chromite mine as well as associated rice fields. The maximum pH (7.4), conductivity $(73 \mu \mathrm{S} / \mathrm{cm}), \mathrm{moisture}$ content (27.43\%) and $\mathrm{Cr}^{6+}$ concentration ( $47.5 \mathrm{ppm}$ ) were observed in the soil from mining area. The $\mathrm{Cr}^{6+}$ content of rice field in the periphery of mining area was $40 \mathrm{ppm}$.

\subsection{Growth of algal isolates at different concentrations of $\mathrm{Cr}^{6+}$}

Table 2 shows the growth of algal isolates at different concentrations of hexavalent chromium ( 0 to $200 \mathrm{mg} / \mathrm{L}$ ). SM3 isolate exhibited the highest growth at $40 \mathrm{ppm}$ of $\mathrm{Cr}^{6+}$ concentration among all the algal isolates while other two isolates SM1 and SM2 exhibited maximum growth at 60ppm and 100ppm, respectively.

\subsection{Growth optimization of the algal isolates}

The growth parameters like incubation period, photoperiod, $\mathrm{pH}$ and inoculum size of the three algal strains were optimised keeping the $\mathrm{Cr}^{6+}$ concentration constant (40ppm) in the media (Fig.2. a, b, c and d.). Maximum algal growth (SM3) was observed in pH 5, 18 hour photoperiod and maximum $2 \mathrm{mg}$ of algal inoculums within 18 days of growth period.

\subsection{Total chromium and $\mathrm{Cr}^{6+}$ analysis}

The percentage of $\mathrm{Cr}^{6+}$ reduction by SM1, SM2 and SM3 isolates presented in Table 3. The results showed that the SM3 algal isolate exhibited the maximum removal capability up to $89.63 \%$ at $40 \mathrm{ppm}$. Therefore, this isolate was taken for further studies.

\subsection{Effect of contact time on $\mathrm{Cr}^{6+}$ removal}

The $\mathrm{Cr}^{6+}$ content in the medium was observed after each 24 hours for five days. The concentration was found to be decreased until $72 \mathrm{hour}$ while after that the rate of removal almost came to a constant point. The initial $\mathrm{Cr}^{6+}$ concentration (40ppm) was decreased to $1.79 \mathrm{ppm}$ within $24 \mathrm{~h}$ and to $1.057 \mathrm{ppm}$ within $72 \mathrm{~h}$ after which the amount became constant (Fig.3).

\subsection{Microscopic and Molecular identification}

Microscopic observation (Fig.4a.) revealed that SM3 is blue green in colour and beaded filamentous in structure. It was characterized by $16 \mathrm{~S}$ rDNA consisting of 20 different closely related strains of Fischerella sp., Nodularia sp., Nostoc sp., Anabaena sp., Kryptousiasp., Cyllindrospermum sp., Cronobergia sp., Iphinoe 
sp., Brasilonema sp., Phyllonema sp. and Chlorogloepsis sp. (Fig.4.b). The optimal tree with the sum of branch length is 0.010 . Percentage of replicate trees in which the associated taxa clustered together in the bootstrap test presented next to the branches. The evolutionary distance was computed using the maximum composite likelihood method and are in the units of the number of base substitutions per site. The phylogenetic tree suggested that this algal isolate belongs to the genus Fischerella sp. with Gene Bank accession numbers (MK422171).

\subsection{Scanning Electron Microscope and EDX and FTIR analysis}

The scanning electron micrographs of SM3 algal isolate $\left(\mathrm{Cr}^{6+}\right.$ treated and untreated) were presented in Fig. 5a, b. No significant variations were found on their cell surfaces. EDX report (Fig.6) inferred that there is no chromium attachment on the surface of SM3 ( $\mathrm{Cr}^{6+}$ treated) sample. Hence, it is confirmed that there is no adsorption of chromium by the algal strain. FTIR spectra of $\mathrm{Cr}^{6+}$ treated and untreated algae are shown in Fig. 7. The FTIR spectral analysis showed that there was a slight shift in the major functional groups. Mostly the alcohols, phenols, primary, secondary amines at $3268.15, \mathrm{~N}-\mathrm{H}$ bond at 1624.19 , carboxylic, esters, aliphatic amines at 1024.02 and alkyl halides at $554 \mathrm{~cm}^{-1}$ were slightly shifted to $3268.70,1626.24,1016.82$ and $543.21 \mathrm{~cm}^{-1}$ respectively.

\subsection{TEM analysis}

The chromium absorption by the algal isolate was studied through TEM. The transmission electron micrographs of Fischerella sp. grown as SM3 (Cr ${ }^{6+}$ treated) and untreated medium was presented in Fig. $8 \mathrm{a}$ and b. The inner cell surface has shown an electron dense layer along with some accumulation of starch surrounding the pyrenoids. The treated cells contain some intracytoplasmic inclusions which were not found in the control cells.

\subsection{Raman Spectroscopy}

Raman Spectroscopy analysis (Fig.9 a, b) revealed that the reduction of $\mathrm{Cr}^{6+}$ in to $\mathrm{Cr}^{3+}$ in cell free medium and SM3 cells, because of the presence of high intense characteristic peak at $600 \mathrm{~cm}^{-1}$.

\subsection{Physico-chemical analysis of the plant samples}

The physiological characteristics of the rice plants such as number of tillers, number of leaves, shoot and root length and dry weight of root and shoot of all treated and control plant samples were presented in Table 4 and Table 5 respectively. Total leaf area, number of grains per panicle and weight of 1000 seeds were presented in Table 6.

\subsubsection{Number of tillers}

The number of tillers was gradually increased till 90 days and from 90 to 120 days it was found to be almost constant in both the seasons. The highest number of tillers were found in the treatment $\mathrm{T}_{3}(15)$ where as the lowest was observed in $\mathrm{T}_{6}(2.6)$ in Rabi, 2018. The number of tillers in Rabi, 2018 was 9.2 in control $\left(T_{5}\right)$ while $T_{1}, T_{2}$ and $T_{4}$ had 10.3, 11.3 and 14.4 numbers of tillers, respectively. In Kharif, 2019, the number of tillers in $T_{1}, T_{2}, T_{3}, T_{4}, T_{5}$ and $T_{6}$ were $11.6,13.6,14.2,13.6,11.5$ and 5.3 respectively.

\subsubsection{Number of leaves}

The number of leaves depended upon the number tillers. So the highest number of leaves was observed in $\mathrm{T}_{3}$ (48.3) treatment because of highest number of tillers during Rabi, 2018 (Table 4). The remaining treatments such as $T_{1}, T_{2}, T_{4}, T_{5}$ and $T_{6}$ were found to have 30.2, 33.2, 40.1, 28.2and 8.3 leaves respectively during their harvesting period in Rabi, 2018. Similarly, in Kharif, $2019 \mathrm{~T}_{4}$ has numbers of leaves (41.4) and lowest in $\mathrm{T}_{6}$ (15.6) (Table 5).

\subsubsection{Root and shoot height}

In Rabi season, the highest root length $(20.6 \mathrm{~cm})$ and shoot length $(112.1 \mathrm{~cm})$ were observed in $\mathrm{T}_{4}$. During the Kharif season, 2019 , the highest root and shoot length were $21.9 \mathrm{~cm}$ and $106.7 \mathrm{~cm}$ in $\mathrm{T}_{4}$ treatment respectively. Lowest root and shoot length were observed in the $\mathrm{T}_{6}$ treatment in both the season. (Table 4 and 5)

\subsubsection{Shoot and root dry weight}

The dry weight of the shoot and root were found to be lower in the $T_{6}$ treatment. There was no significant variation in the dry weight of both the season. The highest dry weight of root and shoot were $13.8 \mathrm{gm}$ and $20.5 \mathrm{gm}$ in Rabi season while in Kharif season, 2019, the dry weight of root and shoot were $14.1 \mathrm{gm}$ and $20.5 \mathrm{gm}$, respectively in $\mathrm{T}_{4}$ (Table 4 and 5)

\subsubsection{Total leaf area}

The total leaf area was calculated on the basis of length and width of the selected healthy leaf. The leaf area was ranged between 25.8 to $40.2 \mathrm{~cm}^{2} \mathrm{in}$ Rabi, 2018 and 25.2 to $40.3 \mathrm{~cm}^{2}$ in Kharif, 2019. Both in Rabi and Kharif season T4 treatment ( 40.2 and $40.3 \mathrm{~cm}^{2}$ ) has shown larger surface area while T6 treatment (25.8 and $25.2 \mathrm{~cm}^{2}$ ) has lesser leaf area like other parameters (Table 6).

\subsubsection{Number of grains/ panicle}

The highest number of seeds were observed in $\mathrm{T}_{4}$ (94) of Rabi season, 2018 and Kharif season, 2019. The lowest number of seeds were observed in T6 (60.6) of Rabi season, 2018 and 62.3 in Kharif season, 2019. Overall number of grains was more in Kharif season than the Rabi season but the difference was not 
significant in some treatment (Table 6).

\subsubsection{Weight of 1000 seeds}

The total weight of 1000 numbers grains was 28.3 and $29.05 \mathrm{gm}$ in case of control plants of Rabi and Kharif season. In other hand, the total weight of 1000 numbers of grains was significantly less in $\mathrm{T}_{6}\left(12.9\right.$ and 13.1) rice plants. The weight of 1000 seeds was more in $\mathrm{T}_{3}(48.8 \mathrm{gm})$ treatment of Kharif season and in $\mathrm{T}_{4}(45.9)$ rice plants in Rabi season, 2018 (Table 6).

\subsection{Biochemical analysis of the plant samples}

The amount of $\mathrm{Chl} \mathrm{a,} \mathrm{Chl} \mathrm{b} \mathrm{\&} \mathrm{total} \mathrm{chlorophyll} \mathrm{content,} \mathrm{total} \mathrm{protein,} \mathrm{carbohydrate} \mathrm{content,} \mathrm{catalase} \mathrm{and} \mathrm{superoxide} \mathrm{radical} \mathrm{of} \mathrm{each} \mathrm{treatment} \mathrm{both} \mathrm{in} \mathrm{Rabi,}$ 2018 and Kharif season, 2019 were presented in Table 7 and 8.

\subsubsection{Chlorophyll estimation of leaf}

The chlorophyll content were ranged between 1.5 to $2.8 \mu \mathrm{g} \mathrm{g}^{-1}, 1.7$ to $4.5 \mu \mathrm{g} \mathrm{g}{ }^{-1}$ and 3.2 to $7.3 \mu \mathrm{g} . \mathrm{g}^{-1}$ for Chl a, Chl b and total chlorophyll respectively during their post harvesting period in the Rabi season, 2018. The amount of pigment was higher in Rabi season, 2019 than Kharif season, 2018. In both the season $T_{1}$ had highest chlorophyll content while $\mathrm{T}_{6}$ had lowest amount of chlorophyll content.

\subsubsection{Estimation of protein content}

The amount of protein content was more in Kharif season than Rabi. The highest protein content was observed in $\mathrm{T}_{4}$ treatment of Kharif season ( $0.9 \mathrm{mg} \mathrm{g}^{-1}$ ). In Rabi season the protein content was ranged between 0.2 to $0.9 \mathrm{mg} \mathrm{g}^{-1}$ while in Kharif season it was laid between 0.2 and $1.05 \mathrm{mg} \mathrm{g} \mathrm{g}^{-1}$. In both the season, the protein content was lowest in $\mathrm{T}_{6}$ treatments (Table. 7 and 8).

\subsubsection{Estimation of carbohydrate content}

The analysis of carbohydrate content was found to be high with high amount of chromium along with the alga. But the $\mathrm{Cr}^{6+}$ treated plants have shown very measurable amount of carbohydrate content. This content was increased consequently with increased amount of $\mathrm{Cr}^{6+}$. The carbohydrate content was higher in Kharif season $\left(7.6 \mathrm{mg} \mathrm{g}^{-1}\right)$ when compared to the same of Rabi season $\left(6.7 \mathrm{mg} \mathrm{g}^{-1}\right)$. Control plants were also produce good amount of carbohydrates in both the season (Table 7 and 8).

\subsubsection{Estimation of catalase activity}

The amount of catalase enzyme was found to be more in Kharif crops as compared to Rabi crops. During Rabi season, this activity ranged from 3.2 to $7.2 \mathrm{U} /$ $\mathrm{mg}$ of protein while in Kharif season it was between 3.4 and $8.8 \mathrm{U} / \mathrm{mg}$ of protein. The activity of enzyme catalase was significantly increased with increase in the concentration of $\mathrm{Cr}^{6+}$ in presence of the alga. Maximum catalase activity was studied in $\mathrm{T}_{1}$ treatment while minimum in $\mathrm{T}_{5}$ of both Kharif and Rabi season (Table. 7 and 8).

\subsubsection{Estimation of superoxide dismutase activity}

SOD activity was increased with increasing concentration of hexavalent chromium. SOD activity was remarkably high during Kharif season, 2019 than Rabi, 2018. In presence of the alga, increase in chromium concentration in soil, enhance the production of SOD. Hence, maximum amount of SOD was noticed in $T_{1}$ both in Kharif ( $9.9 \mathrm{U} / \mathrm{mg}$ of protein) and Rabi season ( $9.1 \mathrm{U} / \mathrm{mg}$ of protein). SOD activity of $\mathrm{T}_{5}$ indicated $3.5 \mathrm{U} / \mathrm{mg}$ of protein in Kharif and $2.2 \mathrm{U} / \mathrm{mg}$ of protein in Rabi. The SOD activity of T6 was lower than that of all other treatments (Table 7 and 8 ).

\subsection{Elemental analysis}

The elemental analysis confirmed that the algal biomass had a good content of nutrients. The chemical composition of the alga was presented in Table 9 . As per the findings, the biomass had some organic compounds like $13.8 \%$ of carbon, $1.54 \%$ nitrogen, $5.39 \%$ hydrogen and $0.15 \%$ sulphur. Similarly, the inorganic compounds like $\mathrm{Ca}, \mathrm{Cu}, \mathrm{K}, \mathrm{Mg}, \mathrm{Mn}, \mathrm{Ni}, \mathrm{Zn}, \mathrm{Fe}, \mathrm{S}$ and $\mathrm{P}$ were measured as2.61, 0.031, 64.1, 4.54, 0.171, 0.06, 0.03, 0.006, 0.15 \pm 0.1 and 14.83mg/l. Though this organism was able to produce such components hence, it can be considered as a bio-fertilizer as well.

\section{Discussion}

The soil sample collected from mining areas showed slightly alkaline $\mathrm{pH}$ which may be due to the manifestation of $\mathrm{Cr}^{6+}$ and mostly it is stable at alkaline $\mathrm{pH}$ (Pattnaik et al. 2017; Das et al. 2013a; Mishra et al. 2010). The control soil sample is slightly acidic in nature (Jena et al. 2008; Dey et al. 2010; Sahoo et al.

2016). The $\mathrm{Cr}^{6+}$ concentration was more in soil sample of mining areas as compared to the soil of rice fields which may be due to the soil runoff of the mining area carries some amount of chromium to rice field. Therefore, the average chromium content of the rice field soil was found to be $40 \mathrm{ppm}$. However, the mine waste soil having high concentration of chromium as reported by several authors (Pattnaik et al. 2017; Dubey et al. 2001; Dhakate et al. 2008).

Three collected algal strains have been tested for maximum growth. Among the three algae, maximum growth was observed in SM3 isolate at $40 \mathrm{ppm}$. The other strains were also resistant to $\mathrm{Cr}^{6+}$ at a range of 0 to $200 \mathrm{ppm} \mathrm{Cr}^{6+}$ concentration because they were isolated from $\mathrm{Cr}^{6+}$ enriched water sample of mining area and exposed for several years to the chromium contaminated regions. This finding was in agreement with the outcomes of Anjana et al. 2007. On the 
basis of dry weight, the maximum growth was obtained in $\mathrm{SM} 3$ isolate at pH 5.0, 18 h photoperiod within 18 days of incubation period with maintaining the $\mathrm{Cr}^{6+}$ concentration at 40ppm. Anjana et al. 2007 reported that the $\mathrm{Cr}^{6+}$ reduction in case of Nostoc calcicola was optimal at $\mathrm{pH} 3.0$. The growth peak for Nostoc sp. was found on the $15^{\text {th }}$ day of inoculation reported by Kiran et al. 2008. These data are quite similar to the findings of the present study. Maximum

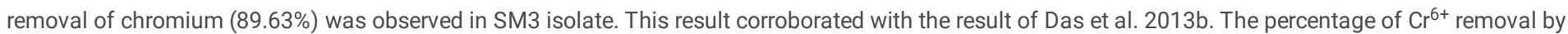
all the isolated strains within $72 \mathrm{~h}$ were found to be significant (87- 89\%). Biosorption of $\mathrm{Cr}^{6+}$ studied by Anjana et al. 2007 who revealed that two native strains

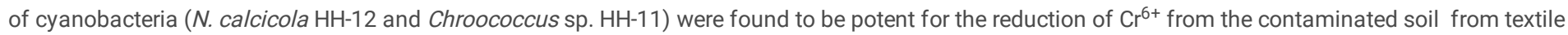

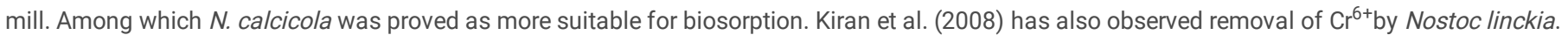

SEM- EDX and FTIR analysis confirmed that adsorption had no significant role in the removal of hexavalent chromium by SM3 isolate. Similar trend of result

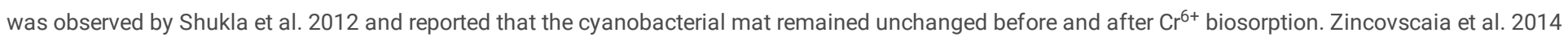
reported that the functional groups (such as $\mathrm{OH}, \mathrm{NH}-\mathrm{CH}_{2}, \mathrm{NH}_{2}, \mathrm{NHC}(\mathrm{O})$ amid, $\mathrm{CH}=\mathrm{CH}$ ) present on the surface of Nostoc linckia which was proved as one of the best studied cyanobacteria for the process of bioadsorption. Although the present study showed the presence of similar functional groups but due to the lack of shifting in the major functional group, it was confirmed that adsorption was not taking place.

The Raman spectroscopy analysis revealed that the reduction of $\mathrm{Cr}^{6+}$ into $\mathrm{Cr}$ (III) by SM3 isolate was quite similar as reported earlier by Das et al. $2013 \mathrm{~b}$ who have used Bacillus amyloliquefaciens collected from the chromite mine. Due to the maximum reduction of $\mathrm{Cr}^{6+}$ to $\mathrm{Cr}^{3+}, \mathrm{SM}^{3}$ isolate was further selected for identification. Microscopic study and molecular characterisation confirmed that the SM3 isolate was Fischerella sp. It was well known for its efficiency in nitrogen fixation (Soltani et al. 2007) and increasing soil fertility (Singh et al. 2014). Hence, this organism can be used in soil, both for the reduction of $\mathrm{Cr}^{6+}$ and the enhancement of soil fertility. The present study revealed that the inner cell surface of Fischerella sp. has an electron dense layer along with some accumulation of starch surrounding the pyrenoids. Andosch et al. (2015) has also studied the severity of $\mathrm{Cr}^{6+}$ along with some other metals through TEM analysis in Desmidium swartzii. They have shown that those metals are readily taken up into the cells, sequestered in intracellular compartments and cell walls hence, affecting the cell ultrastructure, photosynthetic activity and biomass production. Similar ultrastructural changes were also observed by Mota et al. 2015 in Cyanothecesp. and Synechococcus sp. PCC 7942 respectively treated with heavy metals. According to them the ultra structural modifications were mostly included the disintegration and disorganization of thylakoid membranes, increase of the intrathylakoidal space and the presence of inclusions. Goswami et al. 2019 reported that the structural changes that involved the widening of inter membrane space and appearance of noticeable amount of polyphosphate bodies upon the treatment of $20 \mathrm{mg} / \mathrm{l} \mathrm{Cu}$. Hence, from the above study, it was confirmed that removal of $\mathrm{Cr}^{6+}$ was taken place through the reduction (hexavalent $\mathrm{Cr}$ to trivalent $\mathrm{Cr}$ ). The present study is the first report that Fischerella sp. has ability to convert the hexavalent chromium reduced to trivalent chromium having less toxic. $\mathrm{Cr}^{6+}$ was also detected in different plant parts of the rice grown in the rice fields surrounding the mining area. Chromium can be easily transported to different plant parts during the process of absorption and translocation of nutrient from soil.

The amount of $\mathrm{Cr}^{6+}$ was $11.50,0.289,0.119$ and $0.6 \mathrm{mg} / \mathrm{L}$ in root, stem, leaf and grain respectively (Majhi and Samantaray, 2020b). Mohanty et al. 2011 reported that the higher deposition of chromium observed in leaves, stem and grain. Johanto et al. 2018 had also found significant amount of Cr in root, shoot and rice grains $(6.35,2.32$ and $6.65 \mathrm{mg} / \mathrm{kg}$ ) present in chromium polluted paddy fields. Tariq and Rashid, 2013 had observed high Cr content in rice plants (4.28 to $15.54 \mathrm{mg} / \mathrm{kg}$ ) and their grains (4.65 to $12.21 \mathrm{mg} / \mathrm{kg})$. In another experiment, the rice seed germination percentage was found to be high ( $97 \%)$ in seeds treated with $\mathrm{Cr}^{6+}$ and Fischerella sp. (MK422171) as compared to $\mathrm{Cr}^{6+}$ alone. Sundaramoorthy and Ganesh, 2015 showed rice seed germination was $74 \%$ in $\mathrm{Cr}^{6+}$ as compared to control. According to Joshi et al. 2019, the reduction in germination was due to the increase in protease activity and depressive effect of $\mathrm{Cr}^{6+}$ which affect the successive transportation of sugar to embryo axis. The length of rice seedlings amended only with $\mathrm{Cr}^{6+}$ were shorter than that of the control and seedlings treated with $\mathrm{Cr}^{6+}$ amended in presence of the cyanobacterium. Joshi et al. 2019 opined that the length of root become shorter because of the accumulation of $\mathrm{Cr}^{6+}$ in the root vacuoles and hence, collapse the root hairs, decreases root numbers and ultimately, translocates to the shoot and shortens its length. The seed vigour index was more in plants amended with $\mathrm{Cr}^{6+}$ in presence of the alga than that of the positive and negative control plants. Sharma et al. 2018 has reviewed that the seed vigour is an important trait that indicates the seed quality, germination percent, seedling growth \& its longevity and ultimately, it increases the resistance to adverse environmental conditions. Seeds with higher vigour can improve the crop growth and yield. The seed vigour index completely depends upon the shoot and root length of rice seedlings and the seed germination percentage. It means the higher metal concentration is inversely proportional to the seed vigour index. Joshi et al. 2019 has also shown lower seed vigour index in $\mathrm{Cr}^{6+}$ treated seeds than the control.

The present study revealed that the addition of Fischerella sp. in the rice field soil, the pH was changed and became acidic i.e. pH 5.0. It was also reported that acidic $\mathrm{pH}$ is mostly suitable for the rice crop which was possible due to the microbial activity in the soil. The soil EC was also significantly lowered with the inoculation of cyanobacterium in to the soil (Al-Sherif et al. 2015). But plants grew in garden soil and $\mathrm{Cr}^{6+}$ treated soil had shown unchanged in alkaline pH due to the lack of any microbial interaction. The nutrient ( $N, P, K$ and organic $\mathrm{C}$ ) status of the soil get reduced in control and $\mathrm{Cr}^{6+}$ treated soil but get enhanced in the soil treated with $\mathrm{Cr}^{6+}$ with alga. Mohanty et al. 2011 reported that the initial nutrients were less in the soil because of the high contamination of $\mathrm{Cr}^{6+}$ which was increased later due to the interaction of rice plants with biofertilizer. A significant increase in the number of tillers and leaves were observed in soil treated with low amount of $\mathrm{Cr}^{6+}$ and the alga. Although the control plant had shown a good number of tillers and leaves but that was not more than the plant treated with chromium and alga. The alga removes excess toxic chromium present in soil, enhance soil health through nitrogen fixation and addition of dead organic remains (Sahu et al. 2015). Hence, the plant easily gets its micro and macro nutrients for its growth. High chromium concentration in the soil adversely affects shoot and root growth in comparison to control. At low concentration of $\mathrm{Cr}^{6+}$, the algal dose was sufficient to reduce the toxic metal and to lessen its adverse effect on growth of the plant but with the increase amount of $\mathrm{Cr}^{6+}$ concentration, the same amount of algal dose might not be enough to remove the metal completely hence growth was slightly reduced. This might be due to the formation of large blocks of absorbent particles which can provide larger surface area for sorption of metal ions up to a certain limit (Al-Homaidan et al. 2018). However, growth was still higher in the plants treated with both

Page $9 / 20$ 
$\mathrm{Cr}^{6+}$ and the alga than that of both positive and negative controls. According to Sundaramoorthy et al. 2010, chromium toxicity inhibited root cell division and elongation hence, hampers the cell cycle extension. This inhibition in cell cycle extension leads to the reduction of shoot length. Reduced root growth hampers the transportation of nutrients and water to different plant parts and ultimately, lowers the weight of root and shoot (Ojha et al. 2018). Ahmad et al. 2011 reported that the shoot and root growth was reduced at higher chromium concentration $(0$ to $500 \mathrm{mg} / \mathrm{L})$ of chromium. Similarly, the leaf area is completely

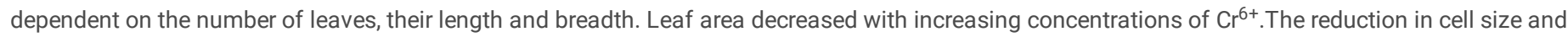
damage to the ultra structure of leaves resulted in declining of cell numbers in leaves and their stunted growth (Sundaramoorthy et al. 2010; Tripathi et al. 2017). The number of grains per panicle and the weight of 1000 seeds were found to be high in plants grown in low chromium containing soil with cyanobacterium $\left(T_{4}\right)$ while the same were found to be less in case of high chromium containing soil with cyanobacterium and negative control ( $\left.T_{5}\right)$. It was least in plants grown in soil treated with high amount of chromium only $\left(T_{6}\right)$ as the number of seeds were too less. Similarly, Sundaramoorthy et al. 2010 reported that the 1000 rice seed weight was $24.78 \mathrm{gm}$ in control while $11.0 \mathrm{gm}$ in treated plants having $200 \mathrm{mg} / \mathrm{L}$ of $\mathrm{Cr}^{6+}$ and it is due to the application of cyanobacterial inoculums which reduced $\mathrm{Cr}^{6+}$ and enhanced plant growth and yield.

On the basis of biochemical analysis, the pigment content decreased with the increase in $\mathrm{Cr}^{6+}$ concentration. But the plant treated with high $\mathrm{Cr}^{6+}$ along with the alga $\left(\mathrm{T}_{1}\right)$ indicated higher chlorophyll content than the plant treated only with $\mathrm{Cr}^{6+}$. This is because the alga was able to grow efficiently by utilising $\mathrm{Cr}^{6+}$ at high concentration of $\mathrm{Cr}^{6+}$ and hence, reduced the $\mathrm{Cr}^{6+}$ concentration of soil and improved the chlorophyll content of the plant. Available reports suggested that the activity of an enzyme $\delta$ - aminolevulinic acid dehydratase involved in chlorophyll biosynthesis is being inhibited due to the excessive amount of chromium in the soil (Hadif et al. 2015). Ghani, 2011 had also reported that high amount of chromium caused stomatal closure, reduction in intercellular spaces and alteration in chloroplast of plants. Chromium has also some deleterious effect on Calvin cycle, electron transport chain and thylakoid membranes by targeting their corresponding enzymes (Sharma et al. 2020). According to Gomes et al. 2017, there is deviation of electrons from the PSI electron donor side due to the presence of heavy metals. Hence, this leads to the inhibition of electron transport chain and disorganization in the ultra structure of chloroplasts which ultimately, leads to reduction in photosynthetic pigment content. However, they have also explained that some of those electrons might be used in the reduction of oxygen molecules which further creates oxidative stress in association with $\mathrm{Cr}^{6+}$. The increase in $\mathrm{Cr}^{6+}$ concentration in soil raise the chromium toxicity level in plants, which is reflected with the loss of chlorophyll from leaves, depletion of crude protein, enzyme content and generation of oxidative stress. But the plants treated with alga were found to possess a good amount of pigment content, protein and antioxidative enzymes (SOD and catalase) activity. This is due to the availability of larger surface area of the alga for $\mathrm{Cr}^{6+}$ sorption and hence, converting the more toxic soil to less toxic. Panda and Choudhury, 2005 have stated that chromium can degrade the protein content in plants. The reduction in protein content may be due to the poor availability of nitrogen. It had also reported that chromium directly affects nitrogen bioavailability by reducing the activity of nitrate reductase involved in the conversion of nitrate to ammonia. Hasan et al. 2017 opined that proteins are the major target of heavy metals. They form complexes with functional groups of protein side chains or shift essential ions, form metallo-proteins, leading to impairment of physiological functions (Tamás et al. 2014). In addition to that, heavy metals also interfere with the native confirmations of proteins by inhibiting folding process of nascent or non-native proteins that manifest both in a quantitative deficiency of the affected proteins and in the formation of proteotoxic aggregates (Bierkens, 2000; Tamás et al. 2014). Moreover, chromium is also associated with the cellular redox activity of plants. A high amount of $\mathrm{Cr}^{6+}$ leads to the generation of more number of reactive oxygen species (ROS) which are virtually interacting with the cellular biomolecules including proteins. Ultimately, this activity encourages damage to proteins (Stambulska et al. 2018; Tripathi et al. 2012).

In conclusion, it is well known that rice plants are highly sensitive towards $\mathrm{Cr}^{6+}$ contamination, resulting in hindered growth and productivity. Physical and chemical methods used to reduce the toxicity of $\mathrm{Cr}^{6+}$ are expensive; hence, it is not advisable for their application in rice field. As an alternative approach bioremediation using algae was proved to be beneficial and eco-friendly. Among three algal strains collected from chromite mining area for the bioremediation of rice field soil. It was observed that SM3 algal strain has a greater potential to reduce $\mathrm{Cr}^{6+}$ to $\mathrm{Cr}^{3+}$. Microscopic study and molecular characterization indicated that SM3 algal strain is identified as Fischerella sp. Moreover, as it is a heterocystous cyanobacterium it can fix atmospheric nitrogen and also enrich in micro and macro nutrient content in soil. It is the first report that this alga strains are growing very well in the chromine mine spoil. Hence, it could be used for the detoxification of $\mathrm{Cr}^{6+}$ contaminated rice fields and to increase the soil fertility status.

\section{Declarations}

Acknowledgement The authors acknowledge to the Department of Microbiology, Central Instrumentation Facility of Odisha University of Agriculture and Technology for providing laboratory facilities to conduct the research work. Authors are also grateful to SRM-DBT, Tamilnadu, India for the 16S rDNA sequencing of the organism.

Author contribution P. Majhi: Indoor and outdoor experiments and data analysis; G. R. Rout: Correction of manuscript, S.M. Samantaray: Original concept and editing of manuscript

Funding This work was not supported by any funding agency.

Availability of data and materials The datasets used and/or analyzed during the current study are available from the corresponding author on reasonable request.

\section{Ethics approval and consent to participate Not applicable}

Consent for publication Not applicable

Competing interests The authors declare no competing interests. 
Disclosure statement No potential conflict of interest was reported by the authors.

\section{References}

Abdel-Ghani NT, El-Chaghaby GA, (2014) Biosorption for metal ions removal from aqueous solutions: a review of recent studies, International Journal of Latest Research in Science and Technology, 3: 24 - 42, http://www.mnkjournals.com/ijlrst.htm.

Ahmad M, Wahid A, Ahmad SS, Butt ZA, Pak, MT, (2011) Ecophysiological responses of rice (Oryza sativa I) to hexavalent chromium, Journal of Botany, 43: 2853-2859

Allen MB, Arnon DI, (1955). Studies on Nitrogen- fixing Blue-green Algae II. The Sodium Requirement of Anabaena cylindrical. Physiologia Plantarum, 8

Anjana K, Kaushik A, Kiran B Nisha R, (2007). Biosorption of $\mathrm{Cr}^{6+}$ by immobilized biomass of two indigenous strains of cyanobacteria isolated from metal contaminated soil, Journal of Hazardous materials, 148: 383-386

Banerjee M, Mishra S Chatterjee J, (2004) Scavenging of nickel and chromium toxicity in Aulosira fertilissima by immobilization: Effect on nitrogen assimilating enzymes, Electronic Journal of Biotechnology, 7: 305-312

Belattmania Z, Tahiri S, Zrid R., Reani A, Elatouani S, Loukili H, Hassouani M, Krati, ME, Bentiss F, Sabour B, (2015) Bioremoval of Hexavalent Chromium from Aqueous Solutions by the Brown Seaweed Dictyopteris polypodioides, Research Journal of Environmental Toxicology, 9: 218-230

Bhattacharyya P, Chakraborty A, Chakrabati K, Tripathy S, Powell MA, (2005) Chromium uptake by rice and accumulation in soil amended with municipal solid waste compost. Chemosphere, 60: 1481-1486

Bender J, Lee RF Phillips P, (1995) Uptake and transformation of metals and metalloids by microbial mats and their use in bioremediation, Journal of Industrial Microbiology, 14: 113-118

Bottomlay PJ, Van Ballen C, (1978) Characteristic of Heterotrophic growth in the Blue- Green Alga Nostoc sp. Strain Mac. Journal of General Microbiology, 107: 309-318

Brahmbhatt RNH, Patel V, Jasrai RT, (2012) Removal of cadmium, chromium and lead from filamentous alga of Pithophora sp. of industrial wastewater. International Journal of Environmental Sciences, 3: doi:10.6088/ijes.2012030131039

Chatterjee A, Abraham J, (2015) Biosorption Capacity of Dried Spirogyra on Heavy Metals, International Journal of ChemTech Research, 8: $387-392$

Das S, Patnaik SC, Sahu HK, Chakraborty A, Sudarshan M, Thatoi, HN, (2013a) Heavy metal contamination, physico-chemical and microbial evaluation of water samples collected from chromite mine environment of Sukinda, India, Trans. Nonferrous Met. Soc., 23: 484-493

Das S, Patnaik SC, Sahu HK, Chakraborty A, Sudarshan M, Thatoi HN, (2013b) Investigation on mechanism of $\mathrm{Cr}^{6+}$ reduction and removal by Bacillus amyloliquifaciens, a novel chromate tolerant bacterium isolated from chromite mine. Chemosphere, http://www.elsevier.com/locate/chemosphere

Davis TA, Volesky B, Mucci A, (2003). A review of the biochemistry of heavy metal biosorption by brown algae. Water Res., 37: 4311-30.

Desikachary TV, (1959) Cyanophyta. Indian Council of Agriculture Research, New Delhi, 686.

Dey HS, Tayung K, Bastia AK, (2010) Occurrence of nitrogen-fixing cyanobacteria in local rice fields of Orissa, India, Ecological Society (ECOS), Nepal, 17: 7785.http://www.ecosnepal.com

Dhakate R, Singh VS, (2008) Heavy metal contamination in groundwater due to mining activities in Sukinda valley, Orissa - A case study, Journal of Geography and Regional Planning. 1: 058-067. http://www.academicjournals.org/JGRP

Dubey CS, Sahoo BK, Nayak NR, (2001) Chromium (VI) in Waters in Parts of Sukinda Chromite Valley and Health Hazards, Orissa, India. Bull. Environ. Contam. Toxicology, 67:541-548. DOI: 10.1007/s00128-001-0157-0

Dwivedi S, Srivastava S, Mishra S, Kumar A, Tripathi RD, Rai UN, Dave R, Tripathi P, Charkrabarty D, Trivedi PK, (2010) Characterization of native micro-algal strains for their chromium bioaccumulation potential: Phytoplankton response in polluted habitats, Journal of Hazardous Materials, 173: 95-101

Elhaddad E, Abeer MA, (2015) Isotherm studies of removal of $\mathrm{Cr}$ (III) and Ni (II) by Spirulina algae. International Journal of Advances in Pharmacy, Biology and Chemistry, 4: 247-251

Esmaeili A, Ghasemi S, Rustaiyan A, (2010) Removal of hexavalent chromium using activated carbons derived from marine algae Gracilaria and Sargassum sp., Journal of Marine Science and Technology, 18: 587-592

Gupta VK, Rastogi A, (2008) Equilibrium and kinetic modelling of cadmium [II] biosorption by nonliving algal biomass Oedogonium sp. from aqueous phase. J. Hazard. Matter, 153: 759-766

Hayat S, Khalique G, Irfan M, Wani AS, Tripathi BN, Ahmad A, (2012) Physiological changes induced by chromium stress in plants: an overview, Protoplasma, 249: 599-611. DOI 10.1007/s00709-011-0331-0.

Page $11 / 20$ 
Jena D, Singh MV, Patnaik MR, Nayak SC, (2008) AICRP on micro and secondary nutrients and pollutant elements in soils and plants. Technical Bulletin 1, OUAT, BBSR

Kavitha G, Sridevi V, Venkateswarlu P, Chitti BN, (2016) Biosorption of Chromium from Aqueous Solution by Gracilaria corticata (Red Algae) and Its Statistical Analysis Using Response Surface Methodology, Open Access Library Journal,3: 2968, http://dx.doi.org/10.4236/oalib.1102968

Katircioglu H, Aslim B, Tunceli A, (2012) Chromium (VI) Biosorption from Aqueous Solutions by Free and Immobilized Biomass of Oscillatoria sp. H1 Isolated from Freshwater, Thelron and Steel Institute of Japan International, 52: 1173-1178

Kiran B, Rani, N. \& Kaushik, A., 2008.Chromium (VI) tolerance in two halotolerant strains of Nostoc, Journal of Environmental Biology, 29: 155-158

Majhi P, Samantaray SM (2020a) Thermo-Tolerant Microalgal Diversity in the Chromium Metal Polluted Sites of Sukinda Mining Area,

Int.J.Curr.Microbiol.App.Sci, 9(3): 1109-1120

Majhi P, Samantaray SM, (2020b) Effect of hexavalent chromium on paddy crops (Oryza sativa), Journal of Pharmacognosy and Phytochemistry, 9(2): 13011305

Majhi P Samantaray SM, (2021) Effect of hexavalent chromium on paddy crops (Oryza sativa), Journal of Pharmacognosy and Phytochemistry, 9(2): 13011305

Mishra H, Sahu HB, (2013) Environmental Scenario of Chromite Mining at Sukinda Valley - A Review, International Journal of Environmental Engineering and Management, 4: 287-292

Mishra V, Samantary DP, Dash SK, Mishra BB, Swain RK, (2010) Study on hexavalent Chromium reduction by Chromium resistant bacterial isolates of Sukinda mining area. Our Nature, 8: 63-71

Monograph on Chromite, (2013) Government of India Ministry of Mines Indian Bureau of Mines

Padhy RN, Nayak N, Dash MRR, Rath, S, Sahu RK, (2016) Growth, Metabolism and Yield of Rice Cultivated in Soils Amended with Fly Ash and Cyanobacteria and Metal Loads in Plant Parts Rice Science, 23: 22-32

Pagnanelli F, Petrangeli PM, Toro L, Trifoni M, Veligo F, (1997) Biosorpotion of metal ions on Arthrobacter sp., biomass characterization and biosorption modeling, Environmental Science Technology, 27: 195-207

Panda SK, Chodhury S, (2005) Chromium stress in plants, Brazilian Journal of Plant Physiology, 17: 95-102

Pandi M, Shashirekha V, Swamy M, (2009) Biosorption of chromium from retan chrome liquor by cyanobacteria, Micribiological Research, 164: 420428. http://www.elsevier.de/micres

Park D, Sangyun S, Park J, (2004) Reduction of Hexavalent Chromium with the Brown Seaweed Ecklonia Biomass, Environmental Science and Technology, 4860-4864

Paudel YP, Pradhan S, Pant B, Prasad BN, (2012) Role of blue green algae in rice productivity. Agriculture and Biology Journal of North America, 3: $332-335$

Pattnaik S, Dash D, Samantaray DP, (2017) Exploration of NPK Activity Showing Chromium Resistant Bacteria from Sukinda Mining Area. International Journal of Current Microbiology and Applied Sciences, 6: 535-542. https://doi.org/10.20546/ijcmas.2017.612.065

Plugaru S, Sarb A, Horcsik TZ, Rusu T, (2016) The effect of chromium on the growth of Chlorella pyrenoidosa algal cultures, Earth Observation and surveying, Environmental Engineering

Razi S, Hasnain S, (2006) Gamma Irradiation: Impact on Chromate Resistant Cyanobacteria, Science Asia, 32: 107-111.doi: 10.2306/science asia1513-1874

Saitou N, Nei M, (1987) The neighbour-joining method- a new method for reconstructing phylogenetic trees. Mol. Biol. Evol. 4: 406-425

Shanker AK, Cervantes C, Loza-Tavera H, Avudainayagam S, (2005) Chromium toxicity in plants. Environ. Int., 31: 739-753

Singhvi P, Chhabra M, (2013) Simultaneous Chromium Removal and Power Generation Using Algal Biomass in a Dual Chambered Salt Bridge Microbial Fuel Cell, Journal of Bioremediation and Biodegradation 4. http://dx.doi.org/10.4172/2155-6199.1000190

Shukla D, Vankar SP, Srivastava SK, (2012) Bioremediation of hexavalent chromium by a cyanobacterial mat, Applied Water Science, 2:245-251.DOI $10.1007 /$ s13201-012-0044-3

Singh SK, Dixit K, Sundaram S, (2014) Effect of acidic and basic pretreatment of wild algal biomass on $\mathrm{Cr}^{6+}$ biosorption, IOSR Journal of Environmental Science, Toxicology and Food Technology, 8: 38-41 http://www.iosrjournals.org.

Soltani N, Khavari-Nejad RA, Yazdi MT, Shokravi S, (2007) Growth and Some Metabolic Features of Cyanobacterium Fischerella sp. FS18 in Different Combined Nitrogen Sources, Journal of Sciences, 18: 123-128 http://jsciences.ut.ac.ir

Page $12 / 20$ 
Stainer RY, Kunisawa R, Mandel M, Cohenbaz G, (1971) Purification and properties of unicellular blue green algae (Order Chroococcales). Bacteriological Reviews, 35: 171-205

Sundarmoorthy P, Chidambaram A, Ganesh KS, Unnikanan P, Bhaskaran L, (2010) Chromium stress in paddy: (i) Nutrient status of paddy under chromium stress; (ii) Phytoremediation of chromium by aquatic and terrestrial weeds. Comptes Rendus Biologies 333: 597-607

Tamura K, Strecher G, Peterson D, Filipski A, Kumar S, (2013) MEGA6: molecular evolutionary genetics analysis version 6.0., Mol. Biol. Evol. 30: 2725-2729.

Vaskova H, Kolomaznik K, (2013) Determination of trivalent and hexavalent chromium by Raman spectroscopy, CORALS-(Conference on Raman and Luminescence Spectroscopy in the Earth Sciences) 105

Volesky B, (2007) Biosorption and me. Water Research. DOI: 10.1016/ 05.062. 41: 4017-4029

Zinicovscaia I, Cepoi L, Valuta A, Rudi L, Culicov OA, Frontasyeva MV, Kirkesali El, Pavlov SS, Mitina T, (2014) Nostoc linckia as Biosorbent of Chromium and Nickel from Electroplating Industry Wastewaters, Journal of Materials Science and Engineering. 4: 242-247

\section{Tables}

Table 1 Physicochemical parameters of the soil samples collected from the opencast mining area and their adjoining rice field.

\begin{tabular}{|lllllll|}
\hline Name of the sample & $\mathrm{pH}$ & $\begin{array}{l}\text { Temperature } \\
(\mathbb{C})\end{array}$ & Moisture content (\%) & $\begin{array}{l}\text { Electrical conductivity } \\
(\mu \mathrm{S} / \mathrm{cm})\end{array}$ & $\begin{array}{l}\text { Total dissolve solid (ppm) } \\
\mathrm{Cr}^{6+} \\
(\mathrm{ppm})\end{array}$ \\
\hline Soil from mining area & 7.4 & $35.3 \pm 0.02$ & $27.4 \pm 0.8$ & $73.2 \pm 0.4$ & $157.8 \pm 1.3$ & $47.5 \pm 0.8$ \\
\hline Rice field soil & 4.96 & $37.4 \pm 0.1$ & $23.5 \pm 0.7$ & $65.4 \pm 0.5$ & $76.7 \pm 0.91$ & $40.4 \pm 0.6$ \\
\hline
\end{tabular}

* The experiment was repeated thrice with three replications

Table 2 Dry weight $(\mathrm{gm} / 100 \mathrm{ml})$ of algal isolates grown in the medium with different concentrations of hexavalent chromium $\left(\mathrm{Cr}^{6+}\right)$.

\begin{tabular}{|llll|}
\hline \multirow{2}{*}{ Different Concentrations of $\mathrm{Cr}^{6+}(\mathrm{ppm})$} & \multicolumn{4}{l}{ Different algal strains } \\
& \multicolumn{3}{l}{ (Dry weight/ 100ml)(Mean average) } \\
\cline { 2 - 4 } & $\mathrm{SM} 1$ & $\mathrm{SM} 2$ & $\mathrm{SM} 3$ \\
\hline 0 & $0.091 \pm 0.001$ & $0.077 \pm 0.001$ & $0.096 \pm 0.0023$ \\
\hline 20 & $0.132 \pm 0.001$ & $0.085 \pm 0.003$ & $0.114 \pm 0.002$ \\
\hline 40 & $0.156 \pm 0.001$ & $0.088 \pm 0.002$ & $0.185 \pm 0.002$ \\
\hline 60 & $0.174 \pm 0.001$ & $0.105 \pm 0.003$ & $0.181 \pm 0.004$ \\
\hline 100 & $0.168 \pm 0.002$ & $0.125 \pm 0.002$ & $0.156 \pm 0.002$ \\
\hline 120 & $0.154 \pm 0.002$ & $0.185 \pm 0.002$ & $0.133 \pm 0.003$ \\
\hline 140 & $0.107 \pm 0.002$ & $0.168 \pm 0.002$ & $0.106 \pm 0.003$ \\
\hline 180 & $0.085 \pm 0.003$ & $0.136 \pm 0.002$ & $0.096 \pm 0.002$ \\
\hline 200 & $0.062 \pm 0.002$ & $0.085 \pm 0.001$ & $0.075 \pm 0.005$ \\
\hline
\end{tabular}

* The experiment was repeated thrice with three replications/concentration.

Table 3 Percentage of $\mathrm{Cr}^{6+}$ available in the respective media after the culture of algal strains. 


\begin{tabular}{|c|c|c|c|}
\hline \multirow[t]{2}{*}{ Different forms of Chromium } & \multicolumn{3}{|c|}{ Algal strains used (Mean \pm S.E)* } \\
\hline & SM1 & SM2 & SM3 \\
\hline Total Cr (ppm) & $4.707 \pm 0.32$ & $4.934 \pm 0.14$ & $4.145 \pm 0.21$ \\
\hline $\mathrm{Cr}^{6+}(\mathrm{ppm})$ & $0.148 \pm 0.002$ & $0.137 \pm 0.06$ & $0.471 \pm 0.02$ \\
\hline $\begin{array}{l}\mathrm{Cr} \text { available other than } \mathrm{Cr}^{6+} \\
(\mathrm{ppm})\end{array}$ & $4.557 \pm 0.51$ & $4.796 \pm 0.17$ & $3.649 \pm 0.55$ \\
\hline Percentage of total $\mathrm{Cr}$ removal (\%) & $88.239 \pm 1.34$ & $87.76 \pm 1.68$ & $89.63 \pm 1.52$ \\
\hline
\end{tabular}

* The experiment was repeated thrice with three replications

Table 4 Growth of rice (Oryza sativa) crop in different treatments during Rabi season, 2018.

\begin{tabular}{|c|c|c|c|c|c|c|c|}
\hline \multirow[t]{2}{*}{$\begin{array}{l}\text { Different } \\
\text { treatment }\end{array}$} & \multirow[t]{2}{*}{$\begin{array}{l}\text { Days after growth } \\
\text { (d) }\end{array}$} & $\begin{array}{l}\text { No. of } \\
\text { tillers }\end{array}$ & $\begin{array}{l}\text { No. of } \\
\text { leaves/plant }\end{array}$ & $\begin{array}{l}\text { Av. root length } \\
\text { (cm) }\end{array}$ & $\begin{array}{l}\text { Av. shoot length } \\
\text { (cm) }\end{array}$ & $\begin{array}{l}\text { Av. D.W. of } \\
\text { root(mg) }\end{array}$ & $\begin{array}{l}\text { Av. D.W. of shoot } \\
\text { (mg) }\end{array}$ \\
\hline & & \multicolumn{6}{|c|}{ Mean $\pm S E^{*}$} \\
\hline \multirow[t]{4}{*}{$\mathrm{T}_{1}$} & $30-d$ & $4.1 \pm 0.5$ & $8.3 \pm 0.3$ & $8.5 \pm 0.3$ & $50.0 \pm 0.4$ & $1.1 \pm 0.1$ & $5.6 \pm 0.3$ \\
\hline & $60-d$ & $6.3 \pm 0.3$ & $19.3 \pm 0.4$ & $9.2 \pm 0.2$ & $72.3 \pm 0.5$ & $7.4 \pm 0.3$ & $8.8 \pm 0.4$ \\
\hline & $90-d$ & $8.6 \pm 0.3$ & $29.6 \pm 0.3$ & $10.7 \pm 0.4$ & $89.7 \pm 0.2$ & $9.9 \pm 0.2$ & $13.7 \pm 0.6$ \\
\hline & $120-d$ & $10.3 \pm 0.5$ & $30.2 \pm 0.5$ & $12.7 \pm 0.8$ & $102.9 \pm 8.2$ & $11.9 \pm 0.7$ & $17.4 \pm 0.2$ \\
\hline \multirow[t]{4}{*}{$\mathrm{T}_{2}$} & $30-d$ & $4.3 \pm 0.3$ & $11.3 \pm 0.3$ & $9.6 \pm 0.6$ & $53.1 \pm 0.9$ & $1.6 \pm 0.1$ & $5.8 \pm 0.2$ \\
\hline & $60-d$ & $6.3 \pm 0.3$ & $19.6 \pm 0.5$ & $11.0 \pm 0.8$ & $76.9 \pm 1.6$ & $7.6 \pm 0.4$ & $9.1 \pm 0.7$ \\
\hline & $90-d$ & $9.2 \pm 0.5$ & $28.6 \pm 0.4$ & $12.6 \pm 0.2$ & $90.9 \pm 1.7$ & $10.9 \pm 0.8$ & $14.2 \pm 0.4$ \\
\hline & $120-d$ & $11.3 \pm 0.3$ & $33.2 \pm 0.5$ & $14.5 \pm 0.3$ & $108.5 \pm 6.2$ & $12.9 \pm 0.9$ & $17.8 \pm 0.5$ \\
\hline \multirow[t]{4}{*}{$\mathrm{T}_{3}$} & $30-d$ & $5.2 \pm 0.5$ & $10.3 \pm 0.3$ & $10.7 \pm 0.4$ & $52.9 \pm 1.4$ & $1.8 \pm 0.1$ & $6.9 \pm 0.4$ \\
\hline & $60-d$ & $10.3 \pm 0.3$ & $28.6 \pm 0.4$ & $12.4 \pm 0.5$ & $84.6 \pm 1.6$ & $10.2 \pm 0.4$ & $10.4 \pm 0.3$ \\
\hline & $90-d$ & $15.1 \pm 0.5$ & $46.4 \pm 0.5$ & $13.5 \pm 0.4$ & $92.9 \pm 1.7$ & $11.9 \pm 0.7$ & $15.9 \pm 0.7$ \\
\hline & $120-d$ & $14.6 \pm 0.3$ & $48.3 \pm 0.4$ & $15.7 \pm 0.3$ & $110.9 \pm 8.3$ & $12.4 \pm 0.4$ & $19.1 \pm 0.2$ \\
\hline \multirow[t]{4}{*}{$\mathrm{T}_{4}$} & $30-d$ & $4.2 \pm 0.5$ & $10.3 \pm 0.3$ & $10.2 \pm 0.4$ & $57.8 \pm 1.4$ & $2.2 \pm 0.2$ & $6.9 \pm 0.2$ \\
\hline & $60-d$ & $8.3 \pm 0.3$ & $24.6 \pm 0.3$ & $13.8 \pm 0.5$ & $90.1 \pm 1.6$ & $10.5 \pm 0.5$ & $10.6 \pm 0.7$ \\
\hline & $90-d$ & $14.4 \pm 0.5$ & $38.2 \pm 0.5$ & $16.8 \pm 0.1$ & $94.6 \pm 0.2$ & $12.6 \pm 0.8$ & $16.7 \pm 0.6$ \\
\hline & $120-d$ & $13.6 \pm 0.3$ & $40.1 \pm 0.3$ & $20.6 \pm 0.3$ & $112.1 \pm 7.5$ & $13.8 \pm 0.6$ & $20.5 \pm 0.5$ \\
\hline \multirow[t]{4}{*}{$\mathrm{T}_{5}$} & $30-d$ & $6.3 \pm 0.3$ & $19.6 \pm 0.3$ & $8.2 \pm 0.2$ & $48.5 \pm 1.8$ & $1.1 \pm 0.09$ & $3.7 \pm 0.1$ \\
\hline & $60-d$ & $8.6 \pm 0.3$ & $23.6 \pm 0.3$ & $10.7 \pm 0.5$ & $71.2 \pm 1.2$ & $6.7 \pm 0.3$ & $9.3 \pm 0.4$ \\
\hline & $90-d$ & $9.2 \pm 0.5$ & $26.4 \pm 0.5$ & $13.1 \pm 0.8$ & $83.5 \pm 0.9$ & $10.8 \pm 0.6$ & $13.4 \pm 0.6$ \\
\hline & $120-d$ & $8.6 \pm 0.3$ & $28.2 \pm 0.5$ & $21.1 \pm 0.4$ & $94.6 \pm 1.1$ & $12.2 \pm 0.3$ & $15.5 \pm 0.4$ \\
\hline \multirow[t]{4}{*}{$\mathrm{T}_{6}$} & $30-d$ & $2.6 \pm 0.3$ & $4.6 \pm 0.3$ & $6.2 \pm 0.3$ & $43.1 \pm 0.8$ & $1.2 \pm 0.03$ & $3.2 \pm 0.1$ \\
\hline & $60-d$ & $3.4 \pm 0.5$ & $5.3 \pm 0.4$ & $7.4 \pm 0.2$ & $49.2 \pm 0.7$ & $2.6 \pm 0.4$ & $5.6 \pm 0.3$ \\
\hline & $90-d$ & $3.6 \pm 0.3$ & $7.6 \pm 0.5$ & $9.2 \pm 0.1$ & $60.5 \pm 1.6$ & $4.8 \pm 0.6$ & $7.8 \pm 0.4$ \\
\hline & $120-d$ & $3.3 \pm 0.3$ & $8.3 \pm 0.8$ & $10.1 \pm 0.5$ & $68.4 \pm 1.8$ & $5.6 \pm 0.5$ & $9.3 \pm 0.5$ \\
\hline
\end{tabular}

* The experiment was repeated thrice with fifteenreplications/treatment ( $p$ value at 0.5 level)

Table 5 Growth of rice (Oryza sativa) crop in different treatmentsduring Kharif season, 2019. 


\begin{tabular}{|c|c|c|c|c|c|c|c|}
\hline \multirow[t]{2}{*}{$\begin{array}{l}\text { Different } \\
\text { treatment }\end{array}$} & \multirow[t]{2}{*}{$\begin{array}{l}\text { Days after growth } \\
\text { (d) }\end{array}$} & $\begin{array}{l}\text { No. of } \\
\text { tillers }\end{array}$ & $\begin{array}{l}\text { No. of } \\
\text { leaves/plant }\end{array}$ & $\begin{array}{l}\text { Av. root length } \\
(\mathrm{cm})\end{array}$ & $\begin{array}{l}\text { Av. shoot length } \\
(\mathrm{cm})\end{array}$ & $\begin{array}{l}\text { Av. D.W. of } \\
\text { root(mg) }\end{array}$ & $\begin{array}{l}\text { Av. D.W. of shoot } \\
(\mathrm{mg})\end{array}$ \\
\hline & & \multicolumn{6}{|l|}{ Mean $\pm \mathrm{SE}^{*}$} \\
\hline \multirow[t]{4}{*}{$T_{1}$} & $30-d$ & $4.3 \pm 0.3$ & $11.3 \pm 0.5$ & $8.3 \pm 0.1$ & $48.7 \pm 0.6$ & $1.1 \pm 0.1$ & $6.8 \pm 0.3$ \\
\hline & $60-d$ & $5.1 \pm 0.5$ & $11.6 \pm 0.3$ & $9.8 \pm 0.3$ & $74.6 \pm 0.8$ & $5.3 \pm 0.6$ & $8.5 \pm 0.4$ \\
\hline & $90-d$ & $11.3 \pm 0.6$ & $27.6 \pm 0.4$ & $11.2 \pm 0.2$ & $88.6 \pm 1.1$ & $11.9 \pm 0.9$ & $13.8 \pm 0.6$ \\
\hline & $120-d$ & $11.6 \pm 0.8$ & $29.3 \pm 0.3$ & $14.8 \pm 0.2$ & $100.6 \pm 5.5$ & $12.4 \pm 1.1$ & $16.5 \pm 0.5$ \\
\hline \multirow[t]{4}{*}{$T_{2}$} & $30-d$ & $5.2 \pm 0.5$ & $9.6 \pm 0.3$ & $9.8 \pm 0.1$ & $54.1 \pm 1.2$ & $1.5 \pm 0.8$ & $7.2 \pm 0.6$ \\
\hline & $60-d$ & $6.6 \pm 0.3$ & $15.6 \pm 0.3$ & $10.4 \pm 0.2$ & $79.1 \pm 1.3$ & $8.6 \pm 0.7$ & $10.1 \pm 0.7$ \\
\hline & 90-d & $11.6 \pm 0.3$ & $38.3 \pm 0.3$ & $13.9 \pm 0.5$ & $89.8 \pm 1.6$ & $12.4 \pm 0.7$ & $14.5 \pm 0.8$ \\
\hline & $120-d$ & $13.6 \pm 0.3$ & $39.5 \pm 0.8$ & $16.5 \pm 0.4$ & $103.8 \pm 6.2$ & $13.6 \pm 0.8$ & $17.4 \pm 0.6$ \\
\hline \multirow[t]{4}{*}{$T_{3}$} & $30-d$ & $8.3 \pm 0.3$ & $21.6 \pm 0.3$ & $11.5 \pm 0.2$ & $55.2 \pm 1.3$ & $1.8 \pm 0.4$ & $6.5 \pm 0.5$ \\
\hline & $60-d$ & $10.6 \pm 0.5$ & $27.3 \pm 0.8$ & $12.9 \pm 0.6$ & $87.9 \pm 2.4$ & $10.9 \pm 0.6$ & $10.6 \pm 0.8$ \\
\hline & $90-d$ & $12.6 \pm 0.3$ & $38.3 \pm 0.3$ & $14.9 \pm 0.4$ & $92.8 \pm 1.3$ & $12.4 \pm 0.8$ & $15.9 \pm 0.7$ \\
\hline & $120-d$ & $14.2 \pm 0.5$ & $37.3 \pm 0.8$ & $19.6 \pm 0.3$ & $105.9 \pm 4.1$ & $13.6 \pm 0.7$ & $19.1 \pm 0.6$ \\
\hline \multirow[t]{4}{*}{$\mathrm{T}_{4}$} & $30-d$ & $5.3 \pm 0.3$ & $17.6 \pm 0.4$ & $11.2 \pm 0.5$ & $56.7 \pm 1.4$ & $2.1 \pm 0.5$ & $8.2 \pm 0.5$ \\
\hline & $60-d$ & $7.6 \pm 0.3$ & $22.3 \pm 0.6$ & $15.2 \pm 0.4$ & $90.6 \pm 1.7$ & $11.4 \pm 0.8$ & $11.5 \pm 0.4$ \\
\hline & $90-d$ & $13.6 \pm 0.3$ & $41.4 \pm 0.5$ & $17.8 \pm 0.6$ & $95.8 \pm 1.6$ & $12.9 \pm 0.7$ & $16.1 \pm 0.3$ \\
\hline & $120-d$ & $13.8 \pm 0.5$ & $39.3 \pm 0.5$ & $21.9 \pm 0.3$ & $106.7 \pm 7.2$ & $14.1 \pm 0.9$ & $20.5 \pm 0.6$ \\
\hline \multirow[t]{4}{*}{$T_{5}$} & $30-d$ & $6.6 \pm 0.6$ & $16.2 \pm 0.5$ & $9.9 \pm 0.3$ & $51.7 \pm 1.2$ & $1.03 \pm 0.2$ & $4.8 \pm 0.4$ \\
\hline & $60-d$ & $8.3 \pm 0.3$ & $16.3 \pm 0.6$ & $11.9 \pm 0.4$ & $69.4 \pm 1.3$ & $5.8 \pm 0.5$ & $10.1 \pm 0.7$ \\
\hline & 90-d & $11.5 \pm 0.5$ & $24.3 \pm 0.6$ & $12.5 \pm 0.6$ & $87.2 \pm 1.4$ & $10.2 \pm 0.8$ & $13.4 \pm 0.8$ \\
\hline & $120-d$ & $10.3 \pm 0.3$ & $26.3 \pm 0.3$ & $18.3 \pm 0.5$ & $96.3 \pm 1.5$ & $10.8 \pm 0.7$ & $14.9 \pm 0.9$ \\
\hline \multirow[t]{4}{*}{$\mathrm{T}_{6}$} & $30-d$ & $2.6 \pm 0.3$ & $9.3 \pm 0.3$ & $7.5 \pm 0.3$ & $43.1 \pm 0.8$ & $0.5 \pm 0.1$ & $3.5 \pm 0.2$ \\
\hline & $60-d$ & $4.3 \pm 0.6$ & $8.6 \pm 0.3$ & $8.6 \pm 0.5$ & $49.6 \pm 0.9$ & $2.2 \pm 0.4$ & $5.7 \pm 0.5$ \\
\hline & 90- d & $5.4 \pm 0.5$ & $14.2 \pm 0.5$ & $9.8 \pm 0.7$ & $62.6 \pm 1.1$ & $3.3 \pm 0.6$ & $7.5 \pm 0.6$ \\
\hline & $120-d$ & $5.3 \pm 0.3$ & $15.6 \pm 0.3$ & $10.5 \pm 0.8$ & $66.9 \pm 1.5$ & $4.4 \pm 0.5$ & $9.4 \pm 0.8$ \\
\hline
\end{tabular}

* The experiment was repeated thrice with fifteen replications/treatment ( $p$ value at 0.5 level)

Table 6 Growth and yield performance of rice crop grown in different treatment during Rabi, 2018 and Kharif, 2019.

\begin{tabular}{|c|c|c|c|c|c|c|}
\hline \multirow[t]{2}{*}{ Different treatments } & \multicolumn{3}{|l|}{ Rabi, 2018} & \multicolumn{3}{|l|}{ Kharif, 2019} \\
\hline & Leaf area $\left(\mathrm{cm}^{2}\right)$ & Grains/ panicle & 1000 seed weight (gm) & Leaf area $\left(\mathrm{cm}^{2}\right)$ & Grains/ panicle & 1000 seed weight (gm) \\
\hline & \multicolumn{6}{|c|}{ Mean (Average) $\pm S E^{\star}$} \\
\hline $\mathrm{T}_{1}$ & $33.4 \pm 1.2$ & $89.3 \pm 1.2$ & $29.5 \pm 0.4$ & $32.5 \pm 0.7$ & $90.4 \pm 1.3$ & $29.6 \pm 0.3$ \\
\hline $\mathrm{T}_{2}$ & $37.1 \pm 1.1$ & $91.4 \pm 0.9$ & $37.2 \pm 0.7$ & $37.8 \pm 0.8$ & $92.6 \pm 1.1$ & $42.6 \pm 0.7$ \\
\hline $\mathrm{T}_{3}$ & $36.9 \pm 0.8$ & $91.6 \pm 1.1$ & $43.3 \pm 0.8$ & $36.2 \pm 0.6$ & $92.8 \pm 0.8$ & $48.8 \pm 0.8$ \\
\hline $\mathrm{T}_{4}$ & $40.2 \pm 0.7$ & $94.2 \pm 0.6$ & $45.9 \pm 0.9$ & $40.3 \pm 0.8$ & $95.3 \pm 0.6$ & $48.3 \pm 0.6$ \\
\hline $\mathrm{T}_{5}$ & $33.9 \pm 0.4$ & $79.4 \pm 0.7$ & $28.3 \pm 0.6$ & $33.7 \pm 0.6$ & $81.5 \pm 0.9$ & $29.0 \pm 0.7$ \\
\hline$T_{6}$ & $25.8 \pm 0.6$ & $60.6 \pm 0.8$ & $12.9 \pm 0.8$ & $25.2 \pm 0.6$ & $62.3 \pm 0.8$ & $13.1 \pm 0.2$ \\
\hline
\end{tabular}

* The experiment was repeated thrice with fifteen replications/treatment ( $p$ value at 0.5 level)

Table 7 Biochemical assay of the rice crop grown in different treatments during Rabi, 2018. 


\begin{tabular}{|c|c|c|c|c|c|c|c|}
\hline \multirow{2}{*}{$\begin{array}{l}\text { Different } \\
\text { treatments }\end{array}$} & \multicolumn{3}{|c|}{ Pigment content $\left(\mu \mathrm{g} \mathrm{g}^{-1}\right)$} & \multirow{2}{*}{$\begin{array}{l}\text { Protein content } \\
\text { (mg/g fresh wt. } \\
\text { basis) }\end{array}$} & \multirow{2}{*}{$\begin{array}{l}\text { Carbohydrate } \\
\text { content (mg/g fresh wt. } \\
\text { basis) }\end{array}$} & \multirow{2}{*}{$\begin{array}{l}\text { Catalase activity } \\
\text { (U/ mg of protein) }\end{array}$} & \multirow{2}{*}{$\begin{array}{l}\text { SOD activity (U/ } \\
\text { mg of protein) }\end{array}$} \\
\hline & $\begin{array}{l}\text { Chlorophyll- } \\
\text { a }\end{array}$ & $\begin{array}{l}\text { Chlorophyll- } \\
\text { b }\end{array}$ & $\begin{array}{l}\text { Total } \\
\text { Chlorophyll } \\
(a+b)\end{array}$ & & & & \\
\hline $\mathrm{T}_{1}$ & $2.8 \pm 0.5$ & $4.5 \pm 0.4$ & $7.3 \pm 0.9$ & $0.5 \pm 0.08$ & $4.7 \pm 0.8$ & $7.2 \pm 0.4$ & $9.1 \pm 0.3$ \\
\hline $\mathrm{T}_{2}$ & $2.5 \pm 0.4$ & $3.3 \pm 0.3$ & $5.8 \pm 0.7$ & $0.6 \pm 0.02$ & $5.4 \pm 0.4$ & $6.7 \pm 0.5$ & $7.8 \pm 0.2$ \\
\hline$T_{3}$ & $1.7 \pm 0.3$ & $2.2 \pm 0.3$ & $3.9 \pm 0.6$ & $0.7 \pm 0.02$ & $5.6 \pm 0.3$ & $6.1 \pm 0.4$ & $5.7 \pm 0.4$ \\
\hline $\mathrm{T}_{4}$ & $1.5 \pm 0.4$ & $2.3 \pm 0.2$ & $3.8 \pm 0.6$ & $0.9 \pm 0.04$ & $6.7 \pm 0.4$ & $4.9 \pm 0.7$ & $3.5 \pm 0.2$ \\
\hline $\mathrm{T}_{5}$ & $1.6 \pm 0.2$ & $1.8 \pm 0.4$ & $3.4 \pm 0.6$ & $0.5 \pm 0.01$ & $5.1 \pm 0.3$ & $4.8 \pm 0.7$ & $2.2 \pm 0.2$ \\
\hline$T_{6}$ & $1.5 \pm 0.2$ & $1.7 \pm 0.2$ & $3.2 \pm 0.4$ & $0.2 \pm 0.08$ & $2.1 \pm 0.2$ & $3.2 \pm 0.8$ & $3.2 \pm 0.1$ \\
\hline
\end{tabular}

* The experiment was repeated thrice with three replications/treatment.

Table 8 Biochemical assay of the rice crop grown in different treatments during Kharif, 2019.

\begin{tabular}{|c|c|c|c|c|c|c|c|}
\hline \multirow{2}{*}{$\begin{array}{l}\text { Different } \\
\text { treatments }\end{array}$} & \multicolumn{3}{|c|}{ Pigment content $\left(\mu \mathrm{g} \mathrm{g}^{-1}\right)$} & \multirow{2}{*}{$\begin{array}{l}\text { Protein content } \\
\text { (mg/g fresh wt. } \\
\text { basis) }\end{array}$} & \multirow{2}{*}{$\begin{array}{l}\text { Carbohydrate } \\
\text { content ( } \mathrm{mg} / \mathrm{g} \text { fresh wt. } \\
\text { basis) }\end{array}$} & \multirow{2}{*}{$\begin{array}{l}\text { Catalase activity } \\
\text { (U/ mg of protein) }\end{array}$} & \multirow{2}{*}{$\begin{array}{l}\text { SOD activity (U, } \\
\text { mg of protein) }\end{array}$} \\
\hline & $\begin{array}{l}\text { Chlorophyll- } \\
\text { a }\end{array}$ & $\begin{array}{l}\text { Chlorophyll- } \\
\text { b }\end{array}$ & $\begin{array}{l}\text { Total } \\
\text { Chlorophyll } \\
(a+b)\end{array}$ & & & & \\
\hline $\mathrm{T}_{1}$ & $2.5 \pm 0.2$ & $4.4 \pm 0.3$ & $6.9 \pm 0.5$ & $0.7 \pm 0.02$ & $5.6 \pm 0.2$ & $8.8 \pm 0.4$ & $9.9 \pm 0.8$ \\
\hline $\mathrm{T}_{2}$ & $1.3 \pm 0.1$ & $2.5 \pm 0.2$ & $3.8 \pm 0.3$ & $0.8 \pm 0.05$ & $5.9 \pm 0.6$ & $7.8 \pm 0.5$ & $8.7 \pm 0.4$ \\
\hline $\mathrm{T}_{3}$ & $1.1 \pm 0.2$ & $1.9 \pm 0.3$ & $3.0 \pm 0.5$ & $0.8 \pm 0.01$ & $6.5 \pm 0.3$ & $6.7 \pm 0.2$ & $6.7 \pm 0.4$ \\
\hline $\mathrm{T}_{4}$ & $1.1 \pm 0.1$ & $1.7 \pm 0.2$ & $2.8 \pm 0.3$ & $1.05 \pm 0.3$ & $7.6 \pm 0.4$ & $5.7 \pm 0.6$ & $5.4 \pm 0.3$ \\
\hline $\mathrm{T}_{5}$ & $0.5 \pm 0.05$ & $1.1 \pm 0.2$ & $1.6 \pm 0.25$ & $0.4 \pm 0.08$ & $5.3 \pm 0.3$ & $4.4 \pm 0.7$ & $3.5 \pm 0.2$ \\
\hline $\mathrm{T}_{6}$ & $0.4 \pm 0.08$ & $0.7 \pm 0.1$ & $1.1 \pm 0.2$ & $0.2 \pm 0.03$ & $1.3 \pm 0.4$ & $3.4 \pm 0.8$ & $3.0 \pm 0.6$ \\
\hline
\end{tabular}

* The experiment was repeated thrice with three replications/treatment.

Table 9 Elemental analysis of the identified cyanobacterium.

\begin{tabular}{|c|c|c|c|c|c|c|c|c|c|c|c|}
\hline \multirow{2}{*}{$\begin{array}{l}\text { Name of the } \\
\text { algal culture }\end{array}$} & \multicolumn{4}{|c|}{ Organic elements (\%) } & \multicolumn{7}{|c|}{ Inorganic elements (ppm) } \\
\hline & $\mathrm{C}$ & $\mathrm{H}$ & $\mathrm{N}$ & S & $\mathrm{P}$ & $\mathrm{Ca}$ & $\mathrm{Cu}$ & $\mathrm{K}$ & $\mathrm{Mg}$ & $\mathrm{Mn}$ & $\mathrm{Ni}$ \\
\hline Fischerella sp. & $13.8 \pm 0.34$ & $5.39 \pm 0.13$ & $1.54 \pm 0.2$ & $0.15 \pm 0.01$ & $14.83 \pm 0.61$ & $2.61 \pm 0.2$ & $0.03 \pm 0.05$ & $64.1 \pm 1.1$ & $4.54 \pm 0.3$ & $0.17 \pm 0.05$ & $0.06 \pm 0$ \\
\hline
\end{tabular}

* The experiment was repeated thrice with three replications

\section{Figures}




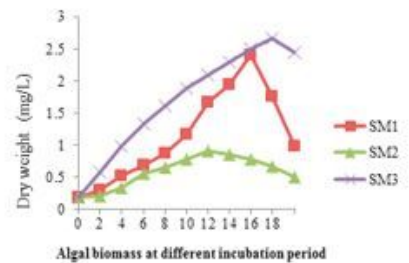

(a)

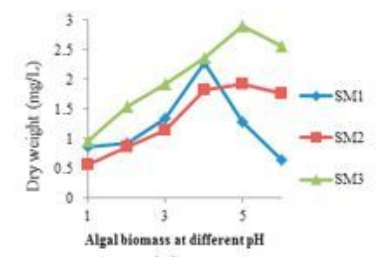

(c)

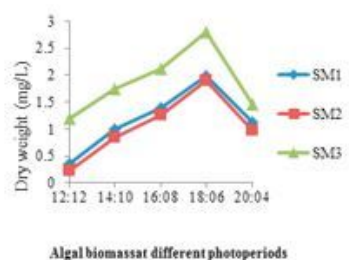

(b)

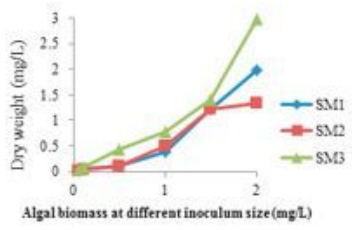

(d)

Figure 1

Optimization of growth of algal isolates in different growth medium: a. Incubation period, b. photoperiods, c. pH, d. inoculum size

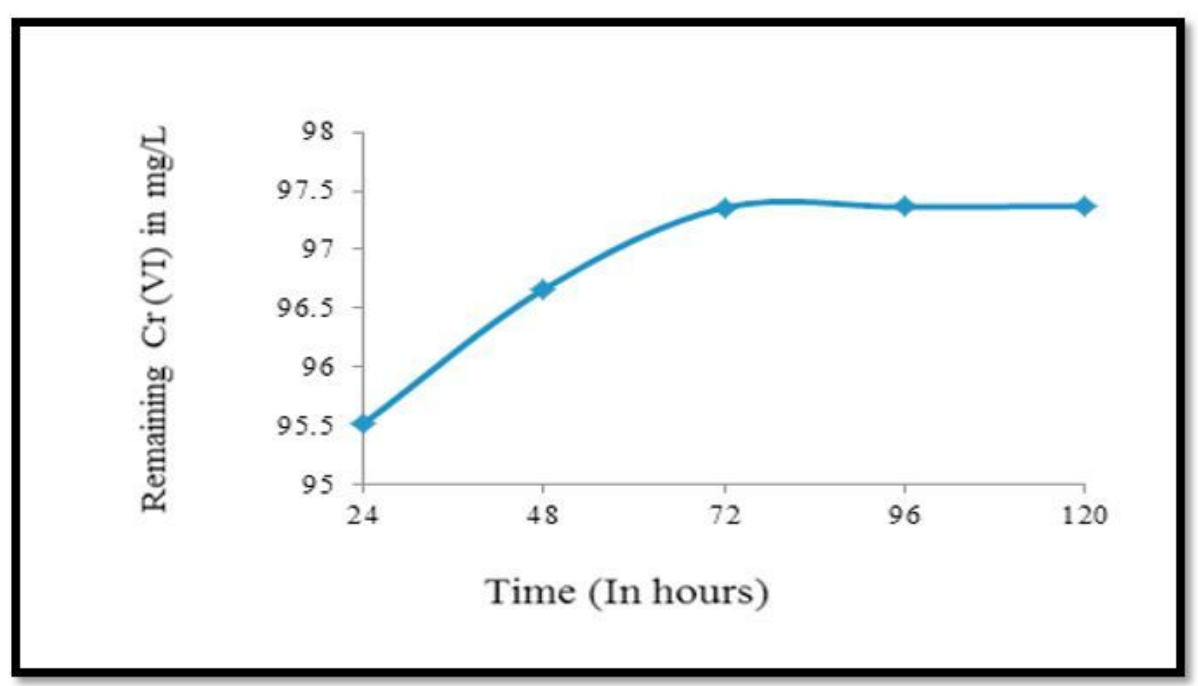

Figure 2

Effect of contact time on removal of Cr6+ 


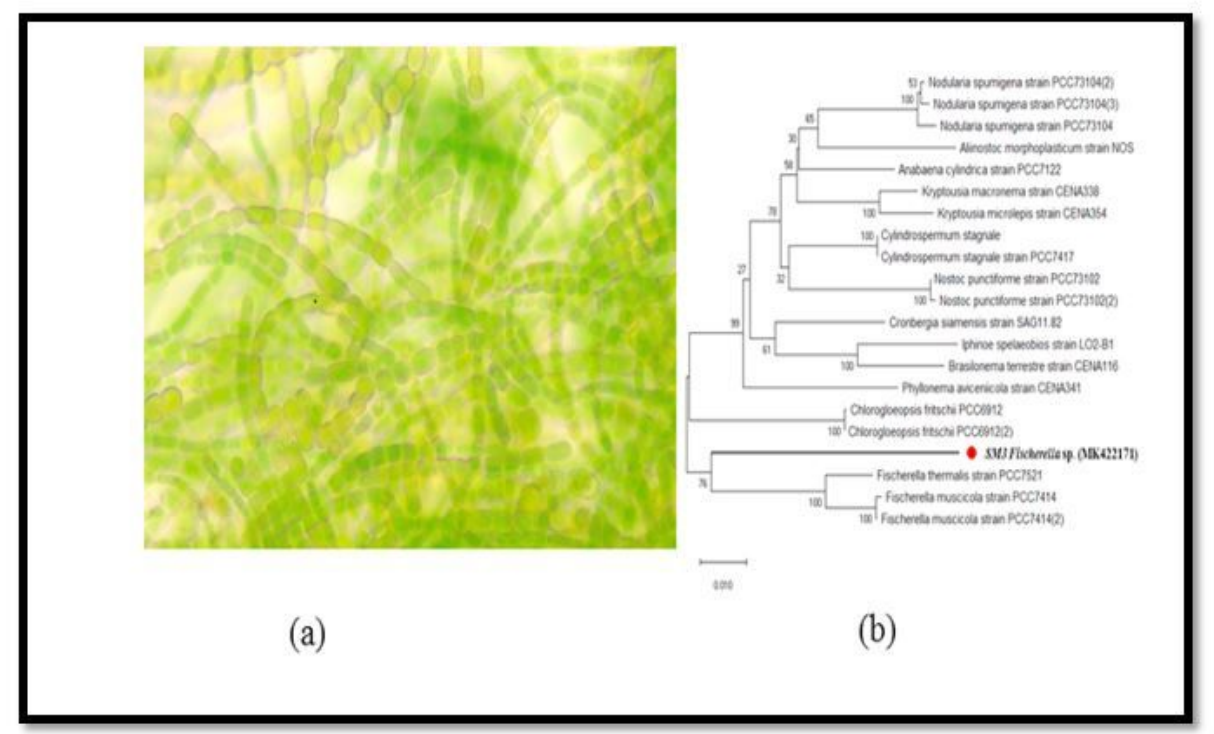

Figure 3

a. Microscopic photograph of the algal strain, b.Phylogenetic analysis of the selected alga

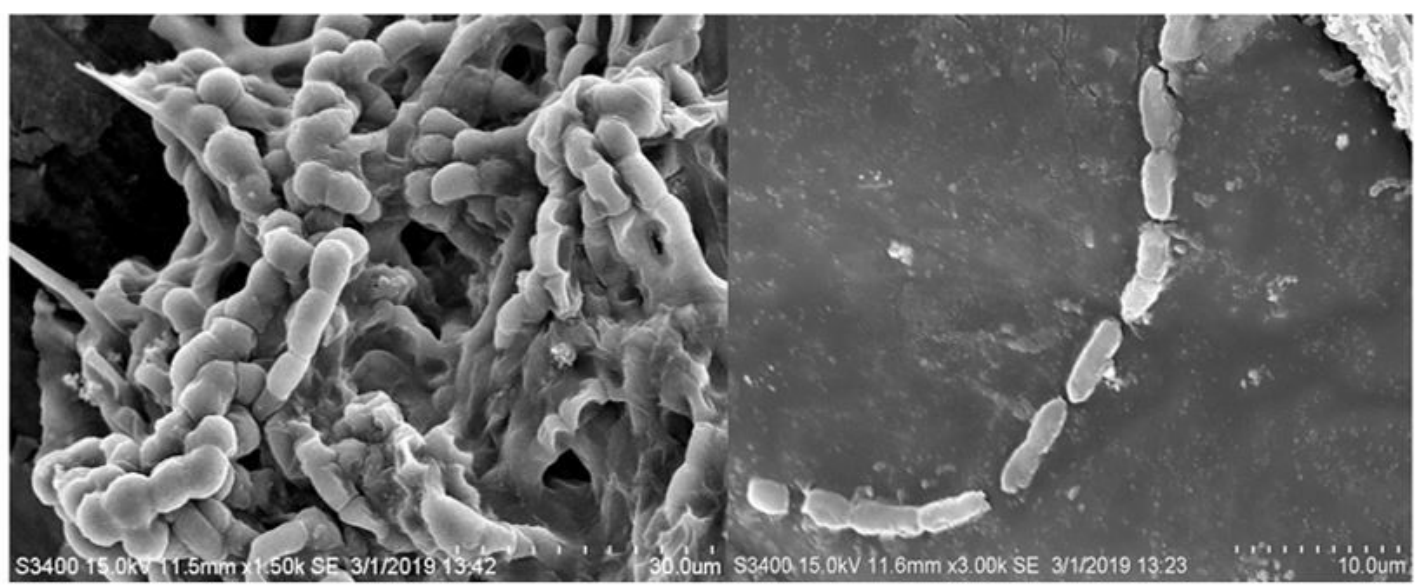

(a)

(b)

Figure 4

SEM micrograph of Cr6+ treated,b. Cr6+ untreated Fischerella sp. (MK422171) 


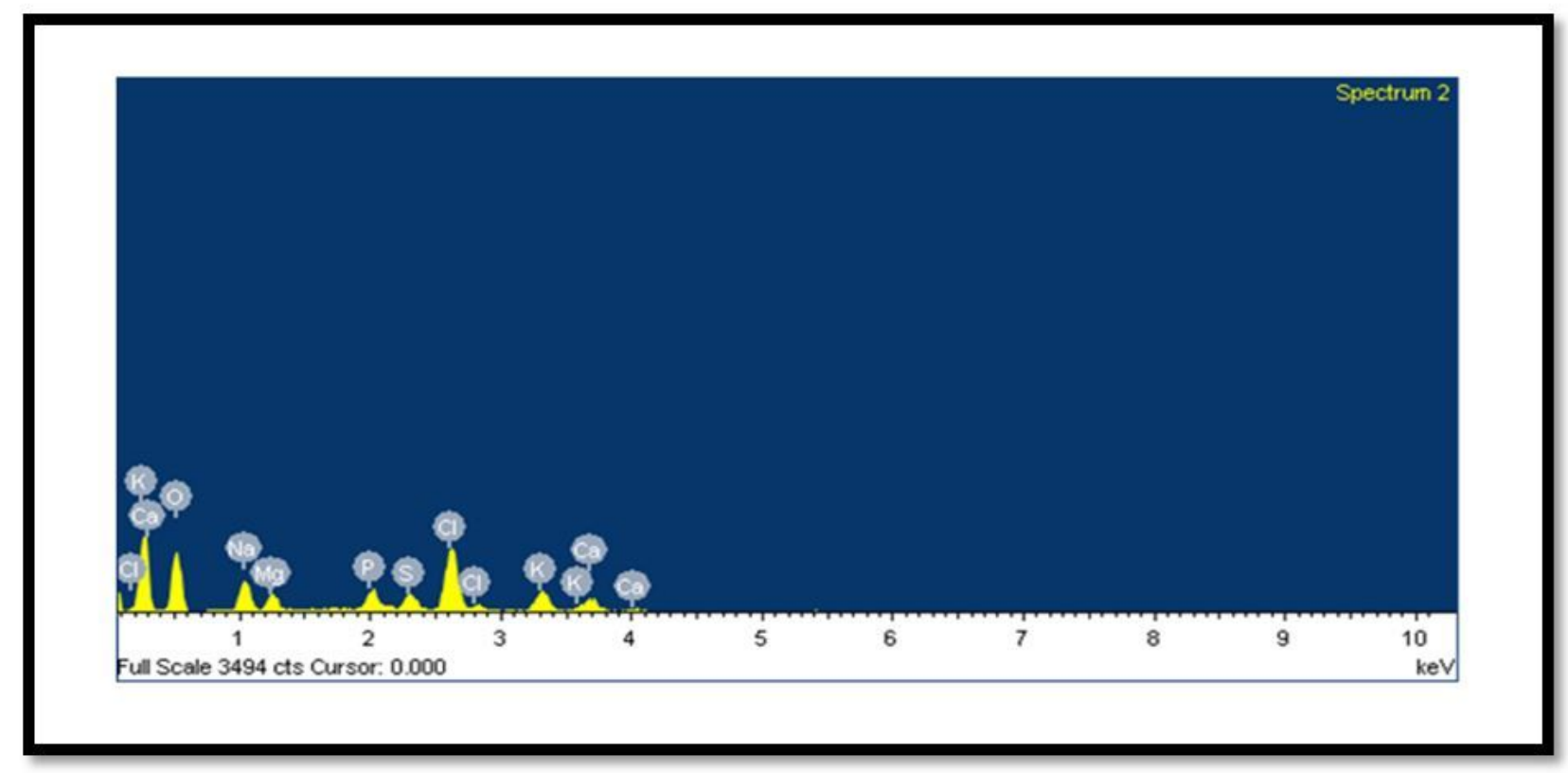

Figure 5

EDX report of Cr6+ treated Fischerella sp.(MK422171)

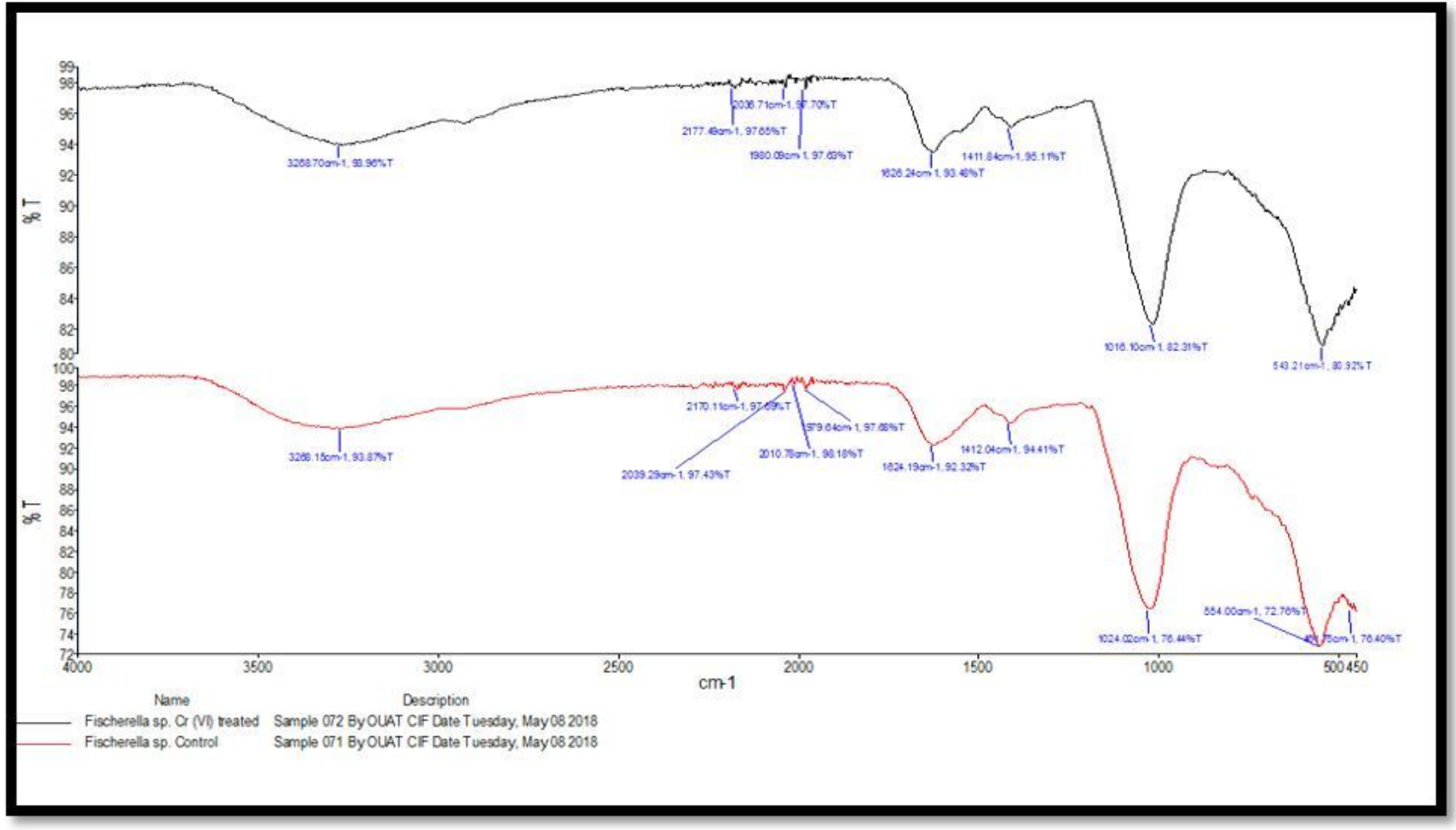

Figure 6

FTIR spectra of Cr6+ treated and untreated Fischerella sp. (MK422171) 


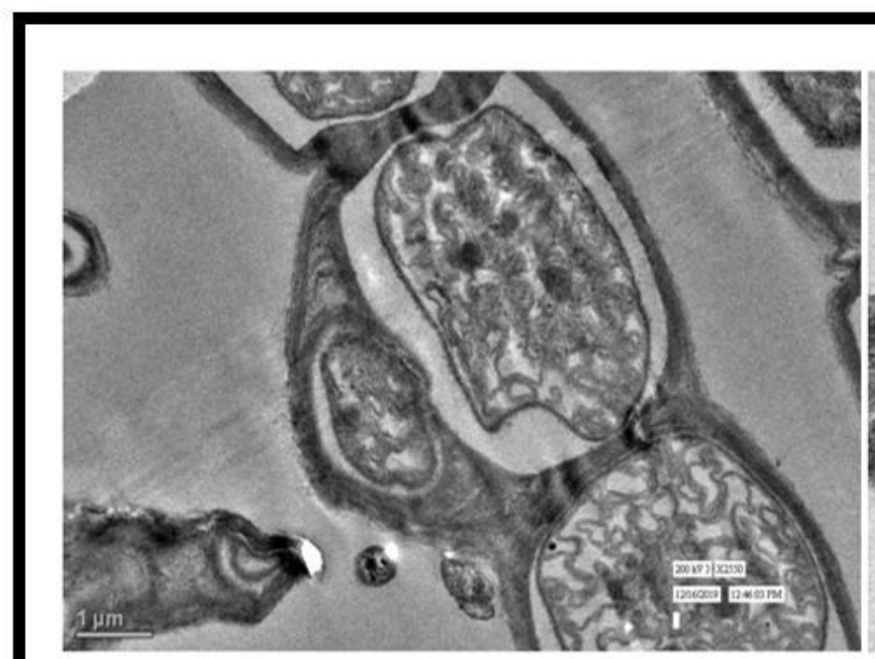

(a)

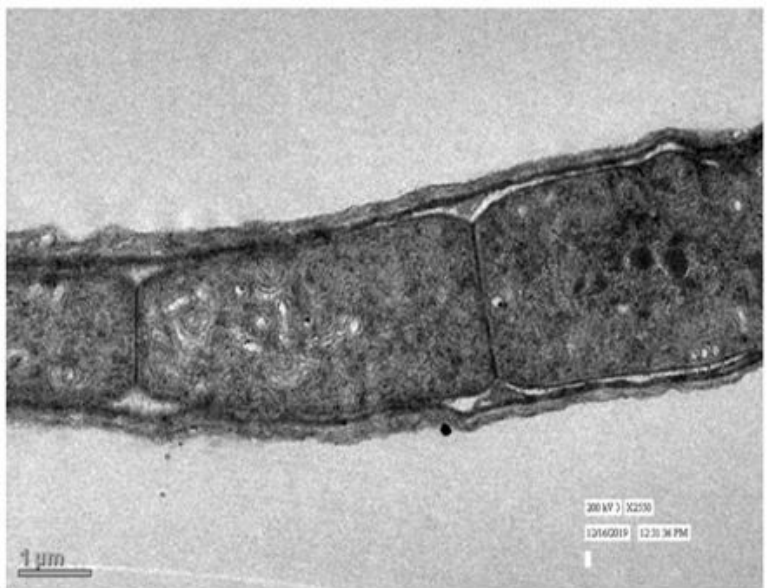

(b)

Figure 7

TEM micrograph of Cr6+ treated and 10.b. untreated Fischerella sp. (MK422171)

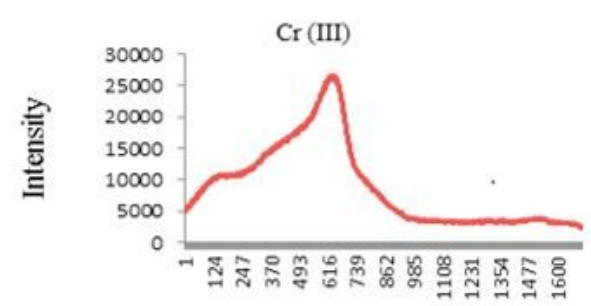

Raman shift $\left(\mathrm{cm}^{-1}\right)$

(a)

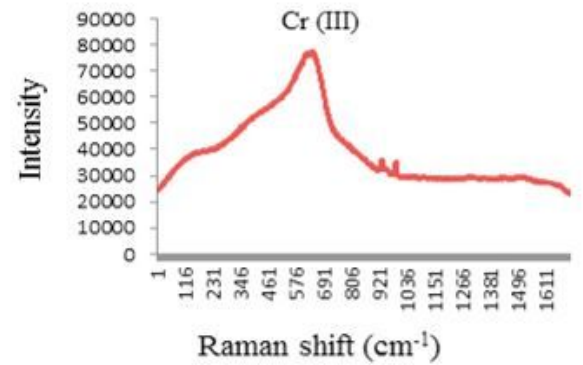

(b)

Figure 8

Raman spectra of a. Fischerella sp. cell free culture medium, b.Fischerella sp. (MK422171) cell itself treated with Cr6+ 